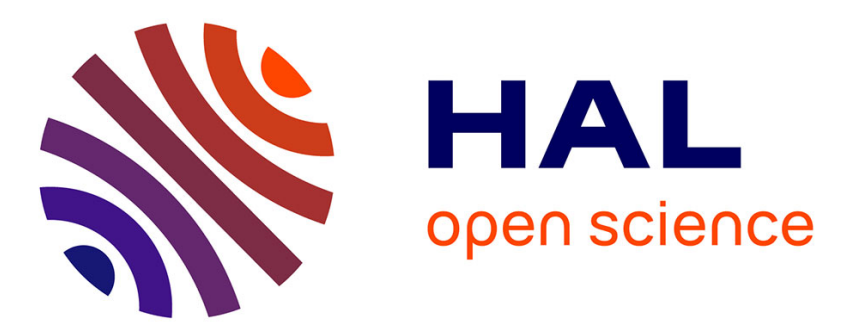

\title{
From accretion to forearc basin initiation: The case of SW Ecuador, Northern Andes
}

\author{
Cesar Witt, J.Y. Reynaud, D. Barba, Marc Poujol, C. Aizprua, M. \\ Rivadeneira, C. Amberg
}

\section{- To cite this version:}

Cesar Witt, J.Y. Reynaud, D. Barba, Marc Poujol, C. Aizprua, et al.. From accretion to forearc basin initiation: The case of SW Ecuador, Northern Andes. Sedimentary Geology, 2019, 379, pp.138-157. 10.1016/j.sedgeo.2018.11.009 . insu-01934568

\section{HAL Id: insu-01934568 https://hal-insu.archives-ouvertes.fr/insu-01934568}

Submitted on 26 Nov 2018

HAL is a multi-disciplinary open access archive for the deposit and dissemination of scientific research documents, whether they are published or not. The documents may come from teaching and research institutions in France or abroad, or from public or private research centers.
L'archive ouverte pluridisciplinaire HAL, est destinée au dépôt et à la diffusion de documents scientifiques de niveau recherche, publiés ou non, émanant des établissements d'enseignement et de recherche français ou étrangers, des laboratoires publics ou privés. 


\section{Accepted Manuscript}

From accretion to forearc basin initiation: The case of SW Ecuador, Northern Andes

C. Witt, J.Y. Reynaud, D. Barba, M. Poujol, C. Aizprua, M. Rivadeneira, C. Amberg

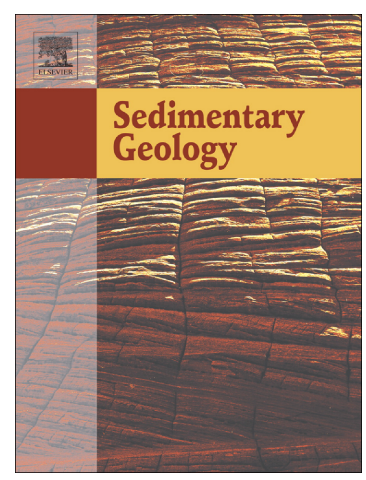

PII: $\quad$ S0037-0738(18)30254-9

DOI: $\quad$ https://doi.org/10.1016/j.sedgeo.2018.11.009

Reference: $\quad$ SEDGEO 5415

To appear in: $\quad$ Sedimentary Geology

Received date: $\quad 18$ August 2018

Revised date: $\quad 15$ November 2018

Accepted date: $\quad 16$ November 2018

Please cite this article as: C. Witt, J.Y. Reynaud, D. Barba, M. Poujol, C. Aizprua, M. Rivadeneira, C. Amberg, From accretion to forearc basin initiation: The case of SW Ecuador, Northern Andes. Sedgeo (2018), https://doi.org/10.1016/j.sedgeo.2018.11.009

This is a PDF file of an unedited manuscript that has been accepted for publication. As a service to our customers we are providing this early version of the manuscript. The manuscript will undergo copyediting, typesetting, and review of the resulting proof before it is published in its final form. Please note that during the production process errors may be discovered which could affect the content, and all legal disclaimers that apply to the journal pertain. 


\section{From accretion to forearc basin initiation: the case of SW Ecuador,}

\section{Northern Andes}

Witt C. ${ }^{1}$, Reynaud, J.Y. ${ }^{1}$, Barba, D. ${ }^{2}$, Poujol, M. ${ }^{3}$, Aizprua, C. ${ }^{1,4}$, Rivadeneira, M. ${ }^{5}$, Amberg, C ${ }^{6}$

${ }^{1}$ Univ. Lille, CNRS, Univ. Littoral Côte d'Opale, UMR 8187, LOG, Laboratoire d'Océanologie et de

Géosciences, F 59000 Lille, France

${ }^{2}$ Petroamazonas EP. Av. Naciones Unidas E-7-95 y Av. De los Shyris. Quito - Ecuador.

${ }^{3}$ Univ. Rennes, CNRS, Géosciences Rennes - UMR 6118, F-35000 Rennes, France.

${ }^{4}$ Department of Geoscience and Petroleum, Norwegian University of science and Technology (NTNU), S.P.

Andersens veg 15a, 7491, Trondheim - Norway

${ }^{5}$ Escuela Politécnica Nacional, Facultad de Geología, Quito-Ecuador

${ }^{6}$ BioStrat Solutions, CAPE pour EDE, 4 Rue des Buisses, 59000, Lille, France

\section{ABSTRACT}

The SW of Ecuador offers a great opportunity to study the long-term behavior of an almost entire forearc system, from the external accretionary prism to the landward limit of the forearc basin. A combination of field observations, LA-ICP-MS U-Pb dating on zircon and interpretation of different vintages of unpublished industrial seismic records are used to study the evolution of the forearc system of SW Ecuador including the accretionary prism and the forearc depocenter. The youngest dates, obtained from $\mathrm{U}-\mathrm{Pb}$ dating on zircon grains believed to be derived from the arc, define the best estimate for the age of sedimentation and permits a clear description of the temporal and spatial evolution of the accretionary, post accretionary and forearc basin series between $60 \mathrm{Ma}$ and $10 \mathrm{Ma}$. This reinforces the idea that forearc sediments 
can be dated by $\mathrm{U}-\mathrm{Pb}$ on zircon provided that the arc is active at the moment of sedimentation. The Azúcar Formation reflects the accretion of SW Ecuador against the South American continental margin from $61 \mathrm{Ma}$ to $55 \mathrm{Ma}$. This event is post-dated by the formation of an accretionary prism which may have started at circa $55 \mathrm{Ma}$. Deformation of the accretionary prism may have been less active during sedimentation of the Ancón Group from 54 Ma (?) to 40 Ma which shows evidence of normal faulting and other extensional processes. The transition from the Azúcar Formation to the Ancón Group is marked by a significant decrease of the topographic profile, which in turn resulted in sedimentary series that shallow upwards. The forearc basin sensu strictu develops coevally with the uplift of the outer forearc high (Estancia Hills) and the sedimentation of the Zapotal Formation at 32-30 Ma; the latest marking a significant differentiation in the sedimentary style of the area to shallower and even continental environments. From $30 \mathrm{Ma}$ to $10 \mathrm{Ma}$ the forearc basin was defined by shallow water deposits, progressively influenced by tidal dynamics, most likely related to a protected triangular bay symbolizing the shape of the forearc basin. Evidence presented here suggests the existence of a stable outer forearc high limiting the forearc depocenter for at least $20 \mathrm{My}$ and creating, at least in part, the accommodation necessary for an $\sim 3 \mathrm{~km}$ thick forearc sedimentary package. The architecture of SW Ecuador is typical of a forearc basin setting including an accretionary prism and an outer forearc high such as those observed in the Kumano (Japan) and the Coast Range and Great Valley basins (USA). The Estancia Hills may correspond to one of the best preserved exposures of an ancient outer forearc high worldwide.

Keywords: forearc basin, subduction, outer forearc high, Ecuador, Andes

\section{Introduction}


During the recent years, our knowledge about how forearc areas evolve trough time has significantly increased thanks to thoughtful examinations of their tectonic and sedimentary evolution (e.g. Noda and TuZino, 2007; Takano et al., 2013, Moore et al., 2015). However, because forearc areas show a great variability (including their accretion or erosional related subduction regime) and a complex history of subsidence very often partitioned in space and time (Xie and Heller, 2009; Noda, 2016), it is still noticeable that the knowledge about how forearc basins evolve through time in the wake of the subduction system, especially in longlived subduction systems, remains poor. Indeed, variations in convergence kinematics (velocity, direction and slab angle), variations of the overburden resulting from erosion of the arc, slab roll-back, subduction-erosion and sediment thickness at the trench, time since initiation of subduction and tectonic escape along partitioned systems are just some of the mechanisms believed to control the forearc basin evolution (Jarrard, 1986; Moxon and Graham, 1992; Einsele et al., 1994; Clift and Vannucchi, 2004; Melnick and Echtler, 2006; Clift and Hartley, 2007; Mitchell et al., 2010; Takano et al., 2013; Moore et al., 2015). The forearc basins might be a clue to hierarchize these varied tectonic controls, but their unravelling is still a challenge because most of them have uncomplete stratigraphic records. Moreover, because tectonic episodes (especially uplift) in the forearc seem to be very short in duration (see review of Pedoja et al., 2014) the record of deformation in forearc basins is often difficult to understand. As a consequence, some forearc basins have been interpreted as evolving independently from the kinematics of subduction (Clift and Hartley, 2007; Takano et al., 2013), whereas others may be strongly coupled to plate kinematics (e.g. Daly, 1989; Regalla et al., 2013). 
It is beyond doubt that a clear definition of basin evolution depends on how accurate the chronology of sediment deposition is defined. Obtaining depositional ages by using $\mathrm{U}-\mathrm{Pb}$ age spectra of zircon grains acquired from volcanoclastic sediments depends mainly on the presence of an active arc at the moment of sedimentation (Cawood et al., 2012; Gehrels, 2014) The Ecuadorian forearc is an excellent candidate to unravel the complicated structuring of forearc areas in the realm of the arc-trench system. Indeed, the SW Ecuadorian margin shows long-lived forearc sedimentation that evolved conjointly with an active volcanic arc since at least the Early Paleocene (Hall and Calle, 1982; Benitez, 1995; Jaillard et al., 1995; Vallejo et al., 2009; Schütte et al., 2010). Furthermore, the SW of Ecuador represents a dichotomy in the common vision of what forearc areas represent, since it shows high sediment preservation, both the accretionary prism and the forearc basin outcrop and, finally, it has been studied, for oil and gas exploration purposes, by the industry. To examine the evolution of the forearc system, we have analysed in detail the sedimentological features of the Paleocene - Late Miocene forearc infilling in SW Ecuador. Chronologic insights are obtained from in situ dating of zircon by LAICP-MS. The combination of sedimentological observations and $\mathrm{U}-\mathrm{Pb}$ dating allow clarifying the chronostratigraphic evolution of SW Ecuador, including the temporal evolution of depositional environments and forearc basin initiation. Seismic records are used to define the regional architecture of the area, including the relationships between a newly defined outer forearc high $(\mathrm{OFH})$ and the forearc basin depocenter. The evolution of the SW Ecuadorian margin resembles that of better studied forearc systems in the Nankai trough (Japan) and in the Great Valley basin (USA). Thus, the SW Ecuadorian margin offers an exceptional opportunity to study an outcropping $\mathrm{OFH}$, a feature whose importance in forearc basin development has gained relevance in recent years (Clift and Hartley, 2007; Takano et al., 2013; Moore et al., 2015; Noda, 2016). 


\section{Forearc development during the Cenozoic}

The forearc of SW Ecuador (Figs. 1 and 2) is central to the debate about the evolution of the southern part of the Northern Andes as it records the oceanic subduction of the Nazca plate, the accretion of allochthonous terranes, Paleogene and Neogene arc magmatism, exhumation of the coastal area and the tectonic escape of the North Andean block. The SW Ecuadorian forearc was formed after the accretion of oceanic terranes with plume and/or island arc affinity such as the Pallatanga and Piñon terranes and their related volcanoclastic covers (Feininger, 1987; Hughes and Pilatasig, 2002; Kerr et al., 2002; Jaillard et al., 2009; Vallejo et al., 2009). There is a major debate about the definition of the nature, number and timing of accretions that led to crust addition and the construction of the Western Cordillera in Ecuador. For some authors, a single Caribbean type accretion may have occurred between 75-65 Ma (Vallejo et al., 2009), whereas other hypotheses suggest multi-episodic oceanic accretions (some of them with no Caribbean affinities) at $\sim 75 \mathrm{Ma}, \sim 68 \mathrm{Ma}$, and $\sim 58 \mathrm{Ma}$ (Feininger, 1987; Hughes and Pilatasig, 2002; Kerr et al., 2002; Jaillard et al., 2009). The oceanic basement has been dated at 90 Ma close to the northern border of the studied zone (Luzieux et al., 2006). In this context, forearc basins most likely evolved in relation with an oceanic crust impinged to the South American margin and which may have acted, at least in part, as an undeformable backstop (Aizprua et al., 2018).

Major tectonic processes (some of them interrelated or competitive) affecting the continental margin of southern Ecuador during the Cenozoic include: 1) Breakup of the Farallon plate at $25 \mathrm{Ma}$ (Handschumacher, 1976; Hey, 1977); 2) Subduction of ocean plate asperities, such as the Carnegie Ridge and the Grijalva Fracture System (Collot et al., 2002; 
Sage et al., 2006; Michaud et al., 2009); 3) Tectonic escape of the North Andean block and related formation of the Gulf of Guayaquil-Tumbes basin (Witt et al., 2006; Witt and Bourgois, 2010) and 4) A subduction-erosion regime working at the plates interface (Bourgois et al., 2007). All of these processes resulted in basin formation or disruption. Thus, the variable localisation and timing of these processes lead to the superimposition of basin depocenters, a process currently poorly understood for the Andean forearc.

The sedimentary record of SW Ecuador starts during the Late Cretaceous with the deepwater volcaniclastic deposits of the Cayo, Santa Elena and Guayaquil Formations (Fig. 3) in an island arc setting. It is believed that afterwards, SW Ecuador was accreted at $\sim 58 \mathrm{Ma}$, a process resulting in the quartz-rich turbiditic deposits of the Azúcar Formation, which constitutes the infilling of an early trench slope basin (Benitez, 1995; Jaillard et al., 1995). After accretion, the forearc of SW Ecuador may have been under extension during the sedimentation of the Ancón Group. It is suggested that compression was then renewed during the Eocene (Jaillard et al., 1995; Jaillard et al., 1997), although this deformation period remains unconstrained. The Paleocene and Eocene series crop out along the Santa Elena Peninsula and along its offshore extension (the Playas High; Fig. 2A). The modern forearc started during the Oligocene with the onset of the Progreso basin, a fault-bordered triangular shaped depocenter located between the Chongón-Colonche hills and the Estancia hills (Fig. 2) and mainly exposing in ascending order the Zapotal, Villingota, Dos Bocas, Subibaja and Progreso Formations (Fig. 3). The forearc sediments show a shoaling trend trough time which has been attributed to several geodynamic factors, such as the kinematics of the subduction system (including accretions) and the subduction of the Carnegie ridge (Benitez, 1995; Jaillard et al., 1995). One of the most accepted models suggests that the extensional deformation leading to the formation of the Progreso basin (mainly controlled by the Carrizal Fault; Fig. 2) resulted from the northwards 
displacement of a forearc sliver (Benitez, 1995). The entire evolution of the forearc is believed to be strongly correlated with plate kinematics (Daly, 1989). Furthermore, uplift is active in several zones of the Peninsula and marked by the presence of Pleistocene marine terraces (Pedoja et al., 2006).

$\mathrm{U}-\mathrm{Pb}$ ages younger than $100 \mathrm{Ma}$ obtained from detrital zircon grains show that the forearc sediments of SW Ecuador were mainly sourced from the Western (Occidental) Cordillera (Ecuador and Peru), which acted as a topographic barrier from $\sim 60 \mathrm{Ma}$ to $\sim 10 \mathrm{Ma}$ and prevented sourcing from inner (eastwards) sections of the Andean Cordillera (Witt et al., 2017). The input of older zircon grains (i.e. older than $100 \mathrm{Ma}$ ) is related to the Amotapes Massif or similar terranes. The onset of exhumation of such a topographic barrier is most likely coeval with the early accretion of oceanic terranes, which took place between 75-65 Ma (Jaillard et al., 2009; Vallejo et al., 2009) although evidence for the accretion in the forearc is, at least in part, younger and dated at $\sim 60-55 \mathrm{Ma}$ (Benitez, 1995; Jaillard et al., 1995; Jaillard et al., 1997; this work).

\section{Sampling and methods}

The chronologic data set used in this work consists of ten new sets of $\mathrm{U}-\mathrm{Pb}$ detrital zircon analyses and ten sets of previously published analyses (Witt et al., 2017) for which the younger age spectra (e.g. <100Ma) were not previously examined. The twenty samples were collected from the Paleocene to the Upper Miocene sedimentary outcrops in the Peninsula de Santa Elena and Progreso basin (Fig. 2). Sampled localities are shown in Figure 2 and listed in Table 1. Samples are tuffs, reworked tuffs and medium-grained sandstones with evidence of 
significant volcanic components. Detailed sedimentary constraints come from field observations whereas tectonic constraints were obtained from field observations and from unpublished industrial seismic records. 2D lines in the Peninsula area were obtained during the eighties whereas seismic lines along the Progreso basin were derived from a 3D seismic cube obtained in 2010. More details are provided in the seismic interpretation section.

$\mathrm{U}-\mathrm{Pb}$ geochronology of zircon grains was conducted by in-situ laser ablation inductively coupled plasma mass spectrometry (LA-ICPMS) at Géosciences Rennes using an ESI NWR193UC Excimer laser coupled to a quadrupole Agilent 7700x ICP-MS equipped with a dual pumping system to enhance sensitivity (Paquette et al., 2014). Concordia ages and diagrams were generated using Isoplot/Ex (Ludwig, 2012). Following the recommendations of Meinheld et al. (2011), Faure and Mensing (2005) and Talavera et al. (2012), the \% of concordance in our study are calculated as \%Conc $=\operatorname{Age}\left({ }^{206} \mathrm{~Pb} /{ }^{238} \mathrm{U}\right) \times 100 / \mathrm{Age}\left({ }^{207} \mathrm{~Pb} /{ }^{235} \mathrm{U}\right)$ for apparent ages younger than $1 \mathrm{Ga}$ and as $\%$ Conc $=\operatorname{Age}\left({ }^{207} \mathrm{~Pb} /{ }^{235} \mathrm{U}\right) \times 100 / \operatorname{Age}\left({ }^{207} \mathrm{~Pb} /{ }^{206} \mathrm{~Pb}\right)$ for apparent ages older than 1 Ga. Dates are displayed either in Tera-Wasserburg concordia diagrams or histograms. Weighted average ${ }^{206} \mathrm{~Pb} /{ }^{238} \mathrm{U}$ dates for the younger clusters are shown in the supplementary materials. All errors given in Table 1 are provided at 1 sigma. In all the diagrams (concordia and weighted average) the data are reported at 2 sigma as well as when ages are calculated. When a concordia age (as of Ludwig, 1998) is calculated, the MSWD value is reported as "concordance+equivalence". Further information on the protocol used in this work can be found in Manzotti et al., (2015); Witt et al., (2017) and in the Complementary Table 1.

\section{Stratigraphic evolution and U-Pb constraints}




\subsection{Youngest $U-P b$ zircon dates point to depositional age}

Detrital zircon age spectra are controlled mainly by the presence of: 1) igneous activity coeval with deposition (primary zircon); 2) the potential of zircon grains preservation and 3) the degree of incorporation of older zircon grains into the sedimentary record (Cawood et al., 2012; Gehrels, 2014; Schoene, 2014). Detrital zircon ages in forearc sedimentary rocks generally show a unimodal distribution with a main population provided by zircon derived from magma emplaced during sediment deposition (Cawood et al., 2012). Gehlers (2014) suggested that if the youngest age decreases progressively up-section, a reasonable interpretation is that measured ages record volcanism during sedimentation. Data presented here come from reworked tuffs and volcanic-rich sandstones with high potential to show a synsedimentary volcanic input. Furthermore, the obtained youngest ages, apart from three exceptions, are systematically younger up-section (Fig. 3) and show a good correlation with paleontological records, mainly those of Ordoñez et al. (2005; see Comp.Fig. 1). We consider that the analyses presented here define the ages of deposition, or ages very close to the deposition age.

To further constraint the relationship between youngest ages and depositional ages we double dated three outcrops (samples CP010-CP011, CP207-CP402 and CP022-CP023). These samples gave comparable ages within error (or very similar ages), thus giving further support for primary zircon input being coeval with sedimentation. Data presented here reinforces the idea that $\mathrm{U}-\mathrm{Pb}$ detrital zircon dating is an excellent tool to date sedimentary series in forearc basins that developed synchronously with and in proximity to an active magmatic arc. Additionally, several grain size fractions $(60-100 \mu \mathrm{m}, 100-160 \mu \mathrm{m}$ and 160-200 $\mu \mathrm{m})$ were dated 
separately in one sample (CP402) and no differences in age clusters were observed between them. Additionally, how accurately the youngest zircon dates constrain the age of sedimentation depends on several aspects including zircon recycling, Pb-loss and uncertainties related to the dating method (1-2\% for LA ICPMS; Dickinson and Gehrels, 2009; Schoene, 2014). It has been proposed by these authors that the difference between the age of deposition and the younger $\mathrm{U}-\mathrm{Pb}$ age may be significantly reduced with high sampling density especially in areas where significant volcanic input is present. Nevertheless, as pointed out by (Dickinson and Gehrels, 2009) the youngest date from a sample will be younger than the true age in almost all cases. The same authors propose that a solution to this too-young bias is to use the age of the youngest group of ages from a sample. Here we consider the youngest clusters defined by at least three analyses that are concordant within error as recommended by Dickinson and Gehrels (2009).

The forearc evolution of SW Ecuador is defined by three main stratigraphic successions that define the accretion, post-accretion, and forearc basin series. Thirteen different sites are described. Site and sample locations are shown in Figure 2. Complementary field pictures and age constraints are shown in Complementary Figure 2 (Com.Fig.2) and weighted average ${ }^{206} \mathrm{~Pb} /{ }^{238} \mathrm{U}$ ages, where possible, are shown in Complementary Figure 3 (Com.Fig.3).

\subsection{The accretion series: the Paleocene Azúcar Formation}

The Azúcar Formation contains the first products of erosion resulting from the accretion of SW Ecuador against the continental South American margin (Benitez, 1995; Jaillard et al., 1995). The accretion event is marked by the first appearance of metamorphic clasts in the 
forearc sediments (Fig. 3D; Luzieux, 2007), as well as the presence of Paleozoic and Triassic detrital zircon $\mathrm{U}-\mathrm{Pb}$ ages (Witt et al., 2017). The last two aspects are believed to constrain sourcing resulting from the erosion of the Amotapes Massif (or other terranes sharing the same age affinities; e.g. Olmos Terrane or Western Cordillera of Peru) located south of the studied area (Witt et al., 2017). Because of different degrees of deformation between the Azúcar Formation and its underlying and overriding series, it has been proposed that both the base and the top of the Azúcar Formation are erosional boundaries (Benitez, 1995). The Azúcar Formation yielded the assemblage of benthic foraminifera such as Rzehakina epionga and Bathysiphon gerochi, the calcareous nannoplankton Heliolithus kleimpellii, Fasciculithus involutus, Cruciplacolithus tenui and Chiasmolithus bidens and palynomorph Foveotriktes margaritae, which are diagnostic of a Paleocene age (Comp.Fig. 1; Ordoñez et al., 2006). Fossil associations suggest a deep sedimentation environment up to 2000-3000 m deep (Ordoñez et al., 2006).

The best outcrops of the Azúcar Formation are located in the SE part of the Peninsula at site 1 (Fig. 2). They display steep NW-SE directed (strike) strata of siliciclastic facies, ranging from shale to conglomerate. The lowermost sections of the Azúcar Formation at site 1A exhibit a typical flysch-like facies (Fig. 4A). The monotonous interbedding, the aggradational pattern and the distribution of strata suggest a low confinement environment, probably related to the depositional fringe of a deep, turbiditic system. The common occurrence of Bathysiphon foraminifera species in these deposits argue in favor of a deep marine setting. A more proximal setting of this system crops out at site $1 \mathrm{~B}$, where the facies is composed of unsorted conglomeratic and thicker sandstone beds (Fig. 4B). The degree of confinement is stronger than at site $1 \mathrm{~A}$. Sandstone beds are pervasively laminated (flat at the base, grading upward to arcuate to crossbeds) with locally fluidization at the top (Comp.Fig. 2A) and bioturbated 
interval observed at the sand-to-sand contacts. These conglomerate-sandstone successions can be interpreted as Lowe sequences of coarse-grained gravity flows emplaced on a westward dipping submarine slope. The feeders of the turbiditic system, found at site 1C (Fig. 4C), correspond to $>10 \mathrm{~m}$ deep channels infilled by conglomerates and coarse-grained sandstones with numerous evidences of by-pass (traction carpets). Conglomerate clasts are mainly composed of well-rounded quartz and dark quartzite or chert. In some places imbrications and crossbeds show a SW directed current. Summarising, the Azúcar Formation at site 1 corresponds to a classical submarine fan sequence of (Walker, 1976), ranging from outer fan sequences at site $1 \mathrm{~A}$ to to suprafan lobes at site $1 \mathrm{~B}$ and inner fan channel fill at site $1 \mathrm{C}$. In site 2, the Azúcar Fm exhibits syn-sedimentary mass wasting structures in conglomeratic facies similar to that at site 1C (Fig. 4D). North of site 6 very fine-grained series affected by intense penetrative deformation may be ascribed to the Azúcar Formation (Comp.Fig. 2B). Alteration patterns suggest the presence of a great amount of fluids. The sedimentary rocks are intensively sheared; although some folded structures are still noticeable. Sedimentary facies and deformation are very different from those observed in other nearby outcrops of the Azúcar Formation (or the Ancón Group, see below).

Four samples of the Azúcar Formation provided zircon dates of various quality, especially with regard to the concordance of youngest grains. This is true for sample CP007 (a massive sandstone; Fig. 4B) as only three of the 10 youngest analyses are concordant within error (Fig. 4E). These three concordant analyses yield a concordia age of $61.2 \pm 2$ Ma (MSWD=2.6). The ten youngest analyses return a weighted average ${ }^{206} \mathrm{~Pb} /{ }^{238} \mathrm{U}$ date of $60.7 \pm$ 0.6 Ma (MSWD=1.2). Sample CP006 (Fig. 4C) yielded 42 apparent ages between $61.8 \pm 0.8$ $\mathrm{Ma}$ and 56.0 $\pm 0.8 \mathrm{Ma}$ with a weighted average ${ }^{206} \mathrm{~Pb} /{ }^{238} \mathrm{U}$ date of $59.9 \pm 0.3 \mathrm{Ma}(\mathrm{MSWD}=1.5$; Comp.Fig. 3). Sample CP103 (a thick sandstone deposit near the Estancia hills; Comp.Fig.1C) 
yields a Concordia age of $57.1 \pm 1.2 \mathrm{Ma}(\mathrm{MSWD}=2.8, \mathrm{~N}=5)$ which is confirmed by the weighted average ${ }^{206} \mathrm{~Pb} /{ }^{238} \mathrm{U}$ date of $57.0 \pm 1.3 \mathrm{Ma}(\mathrm{MSWD}=3.7$; Comp.Fig. 3) obtained from the seven youngest grains (Comp.Fig. 2D). In site 2 (Fig. 2), mass transport deposits includes centimetric boulders (Fig. 4D) with characteristics very similar to the sediments of the Azúcar Formation found at site 1B. One boulder (sample CP107) was sampled from this debris flow. The three youngest concordant data yield a Concordia age of 55.2 $\pm 1.6 \mathrm{Ma}(\mathrm{MSWD}=0.2$, Fig. 4G). In the light of these data, the Azúcar Formation was deposited between $\sim 61 \mathrm{Ma}$ and $\sim 55$ Ma in good agreement with the Late Danian - Late Lutetian age proposed from paleontological records (see Comp.Fig.1; Ordóñez et al., 2006).

\subsection{The Upper Paleocene - Lower Eocene accretionary series close to the Chongón-}

\section{Colonche hills}

Deformed sediments located at site 3 (Fig. 2) have been classically correlated with the Ancón Group by Benitez (1995), although as shown in this work, its sedimentary and compositional characteristics differ from those observed in that group. The outcrop is arranged in a long wavelength antiform with a reference reworked white (tuffaceous) layer observed in the eastward and westward borders (Fig. 5A). The deposit is mostly composed of monotonous whitish volcanosedimentary material with some meter-thick tuff layers in the antiform core. Due to the mineral composition, the fine grain size and conformable parallel bedding, these deposits were likely formed by fallout of volcanic ash in a quiet submarine setting. The western flank of the antiform is slightly overturned (Fig. 5B), whereas the eastern flank dips gently (Fig. 5C). Several normal faults were rotated during the main compressional step, and as for the 
Azúcar Formation deformation in this sedimentary series is most likely younger than the sedimentation.

A thick 4 m laminated tuffaceous layer was sampled (sample CP 212; Fig. 5C). The four youngest zircon analyses return a concordia age of $52.8 \pm 1.3 \mathrm{Ma}(\mathrm{MSWD}=2.4)$. This age is slightly younger than the ages obtained for the Azúcar Formation. The sample also yielded a significant population between 75 and $70 \mathrm{Ma}$. Because of significant sedimentary differences, the fine-grained sediments of the Pacoa area found in site 3 should probably be considered as a different formation, not related with neither the Azúcar Formation nor the Ancón Group

\subsection{The post-accretionary Eocene Ancón Group}

The Ancón Group outcrops along kilometer-scale cliffs in sites 4, 5 and 6 in the west of the Peninsula (Fig. 2A); whereas its lowermost part has hitherto only been observed in seismic records. Outcrops of the Ancón Group have been related to the Seca, Socorro and Punta Ancón formations (see Benitez, 1995 and Ordoñez et al., 2006; Fig. 6), all of them being defined in the past as lithological rather than chronostratigraphic units. Because of the absence of a clear stratigraphic criteria, we made no difference between the Socorro and Seca Formations which are treated as the same unit in the present work. The Ancón Group yielded the calcareous nannoplankton Tribrachiatus orthostylus and Discoaster lodoensis from the eponymous biozones indicating a late Early Eocene (Comp.Fig. 1; Ordoñez et al., 2006). In detail, the Socorro Formation corresponds to the Discoaster binodosus and the lower Tribrachiatus orthostylus calcareous nannoplankton biozones, the Seca Formation to the Tribrachiatus 
orthostylus calcareous nannoplankton Biozone and the Punta Ancón Formation to the Discoaster lodoensis calcareous nannoplankton Biozone (Comp.Fig. 1; Ordoñez et al., 2006).

In site 4, outcrops of the Seca-Socorro sequence exhibit a mud breccia unit, starting by an intraformational conglomerate and passing upward to an olistostrome (Figs. 6A and Comp.Fig. 2F). The intraformational conglomerate is matrix-supported, with angular to subrounded pebbles/cobbles of greyish, laminated sandstones. The matrix is a massive grey silty mud rich in bitumen but some dm-thick, lense-shaped layers have a sandy matrix and a higher abundance of small pebbles. The absence of lamination in the matrix suggests a high density, rapid flow (mudflow). This deposit, ascribed in the literature to the so called Clay-pebble beds unit (see Benitez, 1995), is interpreted as a large debris flow forming a submarine masstransport complex (MTC). The MTC is truncated at the top by a $>10 \mathrm{~m}$ deep channel system infilled by flat-bedded sandstones passing upward to heterolithic strata (Fig. 6A). The massive sandstone beds would correspond to high density bottom flows confined with the channel, whereas the heterolithic beds indicate low density turbiditic spillout deposits. The perfect parallel bedding and very large lateral extent of even the thinnest beds suggest that they are distal, low density turbidites. Many bedsets of the finest-grained facies show convolute bedding with shear structures (that does not affect their thickness regularity), which is consistent with a high sedimentation rate on a submarine slope with the mud breccia beds and slumps being associated with slope failure. Although some meter scale reverse faults are observed (Fig. 6B), deformation at site 4 is mostly extensional and related to meter scale normal faults (Fig. 6C). As no clear extensional regime is observed and deformed series are rapidly sealed, deformation is most likely related to instability pulses of the depositional profile. Further sedimentary observations in site 4 are detailed in CompFigs. $1 \mathrm{G}$ and $1 \mathrm{H}$. 
Site 5 shows a $50 \mathrm{~m}$ thick succession of massive sandstones overlying, with an erosional disconformable surface, a succession of fine-grained, ripple-laminated sandstone and locally organic-rich (peat-like) claystone facies. Olistoliths of the claystone facies, $>1 \mathrm{~m}$ in size, are present at the bottom of the massive sandstone unit (Fig. 6D), which grades upward to the ripple-laminated sandstone and claystone facies. The idealized succession of the facies at this place is a large-scale channel-fill with the massive sandstone, passing upward to the laminated sandstone and claystone forming levee and overbank deposits. A strong energy and discharge are indicated by the supercritical regime in the massive sandstone (namely hummocky cross stratification, HCS) and by the climbing ripples in the overlying laminated deposit (Comp.Fig. 2I). The organic-rich clay, together with the abundance of trace fossils of the Skolithos assemblage, suggest a deltaic setting. Paleocurrents, indicated by the ripples, were toward the south and may be consistent with the paleoslope of the basin. The deformation is related to cmscale normal faults most likely younger than sedimentation (Comp.Fig. 2J).

In site 6 , a more than $200 \mathrm{~m}$ thick section has been correlated with the uppermost series of the Ancón Group (e.g. Punta Ancón Formation; Benitez, 1995). At the base, the series are mostly dominated by an alternation of cross-bedded sandstones and flaky, lignite rich layers, delivering a various collection of large burrows with passive fills (Comp.Fig. 2K). Several beds show Thalassinoid sp. assemblages, whereas others show lignite beds and wood fragments (Fig. 6E). This succession is overlain by a massive sandstone bed $(15-20 \mathrm{~m})$ with metric olistolits and floating coal clasts, where sample CP010 (sandstone) was collected. The massive sandstone grades upward to a poorly stratified, lithic-rich coarse sandstone with stringers of gravels and finally to a massive gravelly conglomerate with lignite clasts and an iron-rich matrix. A metric channeled deposit is observed in this deposit, the base of which being coincident with sample CP011 (tuff, Comp.Fig. 2L). The section terminates by an alternation of 
sand-mud layers with abundant volcaniclasts, mud pebbles and Ophiomorpha. These heterolithic deposits are organized in $2 \mathrm{~m}$-thick sigmoidal bedsets, laterally stacked and truncating each other (Fig. 6F), with superimposed smaller-scale oblique trough crossbedding. The entire section can be interpreted as a forced regressive succession across a fluvialdominated deltaic margin, in concordance with previous observations (Benitez, 1995). The proximity of a terrestrial source is testified by the abundant lignite-rich beds and wood fragments. The heterolithic deposits at the top are interpreted as sinuous channel bars of the deltaic plain, whereas the underlying conglomerate would correspond to the delta front or mouth bar. The overall coarse grain size for this deposit may indicate a still active uplift of the sourcing region.

Sample CP014 was obtained from the base of the sandy series at site 4 . The three youngest zircon analyses yield a concordia age of 54.5 $\pm 1.9 \mathrm{Ma}(\mathrm{MSWD}=3.2)$ confirmed by the weighted average ${ }^{206} \mathrm{~Pb} /{ }^{238} \mathrm{U}$ date of $53.4 \pm 1.1 \mathrm{Ma}(\mathrm{MSWD}=3.3)$ given by the four youngest grains (Fig. 6G and Comp.Fig. 3). Paleontological assemblages suggest a younger age ( 46-44 Ma) for the sandy sedimentation at this site (Ordoñez et al., 2006), although the major debris flow shown in Figures 6A may be older and deposited between $~ 50$ and 46 Ma. Although the low number of young zircon grains dated for sample CP014 prevents to clearly define a true depositional age, the dated grains here are in relatively good correlation (within errors) with the paleontological ages proposed for the debris flow at the base of the unit. The sequence of site 5 is overlain by a volcanic rich tuffaceous deposit, most probably reworked. We collected a similar reworked tuffaceous deposit $10 \mathrm{~km}$ to the north of this area (sample CP017). The six youngest grains are all concordant and define a concordia age of $48.6 \pm 0.6$ Ma (MSWD=1.2). (Comp.Fig. 2M). Because of the facies similarities and similar structural position of the two tuffaceous outcrops we suggest that deposition of the sedimentary series 
observed in the site 4 may have occurred at $\sim 48 \mathrm{Ma}$, an age slightly older than the $\sim 46 \mathrm{Ma}$, which was proposed by Ordoñez et al. (2006) as the older age for these units, based on paleontology. Samples CP010 and CP011 yielded a very significant young component of zircons ranging between 45 and $40 \mathrm{Ma}$, with most likely two different clusters in this range (Figs. 6H and 6I). For sample CP010 (Fig. 6H), the 4 youngest concordant data yield a concordia age of $40.9 \pm 0.6 \mathrm{Ma}(\mathrm{MSWD}=1.8)$. In sample CP011 (Fig. 6I), the four youngest concordant analyses return a concordia age of $40.5 \pm 0.6 \mathrm{Ma}(\mathrm{MSWD}=1.8)$. These ages are in very high concordance with paleontological analysis (Ordoñez et al., 2006), which indicate a 41-40 Ma age (zone P13 of planktic foraminifera; Bolli et al., 1989; Comp.Fig. 1) for the Punta Ancón succession. Samples CP010 and CP011 yielded very important clusters of ages weighted at $43.1 \pm 0.2 \mathrm{Ma}$ and $43.1 \pm 0.4 \mathrm{Ma}$, respectively (Figs. $6 \mathrm{H}$ and $6 \mathrm{I}$ ). Based on these results, the Ancón Group records the transition from the deep-water slope to the deltaic shelf edge of the basin that occurred between $\sim 55 \mathrm{Ma}$ to $41 \mathrm{Ma}$, although further constraints are necessary to better date the base of the group.

\subsection{The Progreso forearc basin and coeval sediments in the North Peninsula}

The Zapotal Formation marks the transition from the accretionary and post-accretionary system to the forearc basin depocenter. Outcrops of the Zapotal Formation are located on the western edge of the Progreso Basin (including its southernmost extension through Puná Island) and are bounded to the west by the Estancia Hills. Indeed, the Estancia hills separates the Paleocene - Eocene series of the Peninsula (west) from the Oligocene-Miocene series of the forearc depocenter (east). In the basin border, eastwards from the Estancia Hills the sedimentary infilling is highly deformed (including sub-vertical strata) and composed of a 
mixture of typical Azúcar and Ancón facies including some cherts most presumably of the Late Cretaceous Santa Elena Formation (Comp.Fig. 2N). The Zapotal Formation holds marine fossils and plants, but there is a lack of diagnostic fossil for biozone. However, some benthic foraminifera were determined at the species level, such as Gyriodina sp., Cibicides sp., Bathysiphon sp. and Rhabdamina sp. The relative age is determined with the position of the sediments and estimated as Oligocene (Comp.Fig. 1; Ordoñez et al., 2006).

Sediment thickness of the Zapotal Formation decreases from approximately $1000 \mathrm{~m}$ in the center of the basin to $\sim 220 \mathrm{~m}$ at the basin border (Estancia Hills; Benitez, 1995). At the type-locality, the Zapotal Formation is composed of tuffaceous sandstone and polygenic, massive, clast-supported conglomerates with rounded elements (Site 7, Fig. 7A). Chert fragments observed in the conglomerate facies are most probably derived from the deeper rocks exposed at the Estancia Hills. The bottom of the conglomerate beds above the sandstones is commonly marked by burrows infilled by gravels, suggesting a kind of firm or hard ground and the sandstones are commonly cross-bedded (Fig. 7B). These facies have been interpreted as deposits related to fluvial and marine shallow water environments (Benitez, 1995).

Sample CP018 (reworked tuff; Fig. 7B), yielded a concordia age of $32.5 \pm 0.9 \mathrm{Ma}$ $(\mathrm{MSWD}=2.8, \mathrm{~N}=4$; Fig. $7 \mathrm{C})$ and a weighted average date of $32.5 \pm 0.3 \mathrm{Ma}(\mathrm{MSWD}=0.4$; Comp.Fig. 3) calculated with the 10 youngest grains (Fig. 7C). The sandstone sample CP218 obtained from NW Puná Island (Comp.Fig. 2O) yielded a concordia age of $29.6 \pm 0.4 \mathrm{Ma}$ $(\mathrm{MSWD}=0.2 ; \mathrm{N}=5 ;$ Fig. 7D) and a weighted average date of $29.5 \pm 0.4 \mathrm{Ma}(\mathrm{MSWD}=2.5)$ obtained with the 15 youngest grains. The ages obtained here suggest that the Zapotal Formation was deposited during the earliest Oligocene; thus redefining the Oligocene 
undifferentiated age proposed from paleontological assemblages and constraining the forearc basin initiation at around 32-29 Ma.

The forearc basin deposit continued in the early Miocene with the sedimentation of the Dos Bocas and Villingota Formations. Outcrops of the Dos Bocas and Villingota Formations are very sparse in the Progreso basin depocenter and confined to a strip parallel to the Estancia hills (Fig. 2). In the northernmost areas of the Santa Elena Peninsula, a shallow-water series ascribed to the Dos Bocas Formation outcrop in Site 8 in the Montañita area (Fig. 2A). The outcrop consists of a succession of units of yellowish litharenites and sandstones bounded by low angle unconformities (Fig. 8A). The deposits are parallel bedded or structureless, with locally large diagenetic nodules. The beds are bounded and traversed by boxworks of large arthropod burrows (Comp.Fig. 2Q). They also exhibit marine mammal bones (Comp.Fig. 2R) and some patch reefs of bivalves and worms are locally found. These beds were deposited in a protected shallow-water setting, likely under a period of strong tectonic deformation (as indicated by the progressive unconformities). Near the axis of the Progreso basin, outcrops ascribed to the Dos Bocas Formation (Fig. 2B) are observed in site 9 (Fig. 8B); it consists of a flat bedded tuff arenite with superimposed symmetrical ripples, passing upward to hummocky crossbeds. It is incised at the top by a channel, several meters deep, floored by a tuff conglomerate. These facies are typical of the succession expected in shoreface bars and rip channels.

Sample CP705 (sandstones attributed to the Dos Bocas Formation) yielded a concordia age of $23.5 \pm 0.4 \mathrm{Ma}$ (MSWD=0.7; N=3; Fig. 8C and Comp.Fig. 3). The eight youngest grains return a weighted average date of $22.9 \pm 0.6 \mathrm{Ma}(\mathrm{MSWD}=4$; Comp.Fig. 3). This depositional age is in high concordance with paleontological records. Indeed, the Dos Bocas Formation 
shows a great abundance and diversity of fossils; there are planktic foraminifera, radiolarians and numerous calcareous nannoplankton. The base of the formation yielded diagnostic fauna indicating the early Early Miocene Cyrtocapsela tetrapera radiolarian Biozone (Comp.Fig. 1; Ordoñez et al., 2006). The U-Pb age is also coincident with the age proposed for a dolphin skeleton recently found in the same unit in the Montañita area and dated as Chatian (upper Oligocene, 26-24 Ma; Tanaka et al., 2017); and 2) previous macro and micro fauna observations from Bristow (1975). Sandstones samples, CP702 (Dos Bocas Formation) and CP019 (Villingota Formation), near the basin border, did not yield a depositional age component (Figs. 8D and 8E) and the extensive record of $\sim 30 \mathrm{Ma}$ and $\sim 43 \mathrm{Ma}$ zircons is believed to be derived from erosion of the Zapotal Formation and the Ancón Group, respectively. Similarly, an outcrop attributed to the Subibaja Formation (sample CP021; Comp.Fig. 2P) showed a representative family at $\sim 60 \mathrm{Ma}$ and 3 zircon grains at $\sim 30 \mathrm{Ma}$, which are ascribed to the Azúcar and Zapotal Formations, respectively. From all our dated samples, CP702, CP019 and CP021 are the only ones in which the youngest dates are not related to the depositional age. Not coincidentally, these samples are: 1) close to the main structural high of the Progreso basin, which suggests that reworking processes are stronger within sedimentary rocks located near to the structural high and 2) coeval with basin-inversion processes taking place at the NE basin limit (see seismic interpretation section). Furthermore, three other analyzed samples of the same formations near the Estancia Hills did not contain any zircon grain.

Site 10 corresponds to the type-locality of the Subibaja Formation The Subibaja Formation show diagnostic foraminifera from the Globigerinatella insueta, Globorotalia foshi peripherodonda and Globorotalia foshi foraminifera biozones, indicating a Middle Miocene age for that formation (Comp.Fig. 1; Ordoñez et al., 2006). The lower part of the section is 
composed of a silty, volcaniclast-rich mudstone (Fig. 9A) with numerous nodules and pipes that are likely related to early diagenesis. Due to the absence of tractive bedforms, and the occurrence of many floating bivalve shells in connection, this facies is interpreted as a lower offshore setting. The overlying deposits are coarsening upward and show a progressive return of current action at the sea-bed, by way of offshooting ripples, interpreted as wave ripples, which indicate an upper offshore setting (Comp.Fig. 2S). The offshore deposits are overlain by a regressive facies tract, composed of a volcaniclastic litharenite comprising hummocky crossstratification (HCS), Ophiomorpha and cross strata infilling channels at the top. The HCS would correspond to shoreface deposits and the cross strata, which comprise upper-plane bedding, is interpreted as foreshore runnel infill. The sharp erosion at the bottom of the coastal facies and the lesser preservation of the shoreface argue in favor of a forced regression at this point. Similar downward shifts of facies are observed near the Zacachun locality (Fig. 2A), where oyster patch reefs overlie the shoreface deposits by way of a regressive surface of marine erosion. These features are the hint of a reduced subsidence in these formations. Sample CP405, taken from a tuffaceous interval in this outcrop, yielded a concordia age of $15.6 \pm 0.2$ Ma (MSWD=1.5; N=7; Fig. 9E) identical within error with the weighted average date of $15.9 \pm$ $0.3 \mathrm{Ma}$ (MSWD=1.7; Comp.Fig. 3) calculated with the 11 youngest grains. Similar downward shifts of facies are observed near the Zacachun locality (Fig. 2A), where oyster patch reefs overlie the shoreface deposits by way of a regressive surface of marine erosion.

Three outcrops of the upper part of the Subibaja Formation are exposed at site 11, near Las Juntas (Fig. 2A). Although it was not possible to structurally correlate these outcrops, they show similar successions of facies and might represent lateral equivalents. The lower part of the section exhibits loose, gravelly sand and litharenite with a gastropod fauna indicative of freshwater to brackish water. It is therefore interpreted as a fluvial to estuarine proximal 
channel deposit (Fig. 9B). This facies is erosionally overlain by a finer-grained facies, either sandy and structureless, with long vertical burrows (Rosselia ?), crossbedded with mud drapes (Fig. 9C), or locally flat bedded with rhythmic mud drapes interstatified. A Glossifungites facies lies in between, infilling large arthropod burrows (Comp.Fig. 2T). The mud drapes (Fig. 9C) is interpreted as the effect of tidal dynamics, and the Glossifungites surface as a transgressive surface. The dominant tidal paleocurrent measured in this level is toward the east, which indicate a flood dominance. The upper part of the outcrops is composed of cross-bedded gravelly sandstone with mud pebbles at the bottom, and locally containing silicified wood logs. The crossbeds indicate paleocurrents toward the west. It is interpreted as the return to a fluvial or deltaic setting. We collected two sandstone samples from site 11A (CP207 and CP402), from which eleven concordant grains from sample CP207 yield a concordia age of $14.2 \pm 0.3 \mathrm{Ma}$ (MSWD=1.6, Comp.Fig. 2W) and in sample CP402, 36 grains yield a concordia age of $14.3 \pm$ 0.1 Ma (MSWD=1.5). The 50 youngest grains return a similar weighted average date of $14.2 \pm$ $0.1 \mathrm{Ma}(\mathrm{MSWD}=2)$. Thus, at site 10 and 11, spanning about $2 \mathrm{Ma}$, the Subibaja Formation records relative sea-level falls in a siliciclastic setting ranging from the outer shelf to the shoreline, with incised valleys and embayments influenced by tidal dynamics.

The Progreso Formation is exposed at Sites 12 and 13. According to the literature (Benitez, 1995) it corresponds to the last marine transgression over the area, after a fluvialdominated sedimentation at the top of the Subibaja Fm (Zacachun Mb.). The base of the Progreso Formation holds Globigerina nepenthes and Globorotalia siakensis, an assemblage corresponding to the Middle Miocene, whereas the upper part of the formation has a Late Miocene age (Comp.Fig. 1; Ordoñez et al., 2006). The two studied outcrops exhibit agradational units of large lateral extent. In site 12, each unit (about 2-5 m thick) has a sharp bottom, underlined by a dense network of Thalassinoides (Comp.Fig. 2U). This surface is 
overlain by oyster patches, grading upward to a muddy calcarenite with numerous Skolithos and Cylindrichnus burrows (Fig. 9D). The upper part of the unit is a fine-grained calcarenite with mud drapes. These units are interpreted as high frequency, transgressive systems tracts. In site 13 (Comp.Fig. 2V) the deposits are more siliciclastic and tuff-rich. They are dominantly composed of poorly bedded muds, with a sharp bounded, $8 \mathrm{~m}$-thick interstratified sandy unit composed at the bottom by convolute beds, grading upward to large-scale trough crossbeds, the bottom of which is underlined by thick mud drapes. The muddy background is interpreted as a shelf highstand deposit, and the interstratified sandy unit as a forced regressive delta-front, the top of which being reworked into dunes in a tide-influenced setting (mud drapes). Two samples, $\mathrm{CP} 022$ and $\mathrm{CP} 023$, were collected in the deltaic facies from a reworked tuff and a sandy layer, respectively. Dating on sample CP022 shows three subconcordant grains with ages comprised between 11.5 Ma and 10.5 Ma (Comp.Fig. 2X). In sample CP023, three concordant grains yield a concordia age of $10.3 \pm 0.2 \mathrm{Ma}(\mathrm{MSWD}=0.9$; Fig. $9 \mathrm{G})$ whereas the five youngest grains return a weighted average date of $10.2 \pm 0.4 \mathrm{Ma}(\mathrm{MSWD}=4.5$; Comp.Fig. 3 ). These data confirm the Tortonian depositional age obtained for the CP022 sandy sample.

\section{Seismic interpretation}

Five key lines (Figs. 10 and 11) have been chosen from a set of hundreds (including different 3D seismic cubes) to show the accretionary, post accretionary and forearc basin series (line location is shown in Fig. 2). The seismic lines of Figure 10 were obtained during the 1980's whereas the 2D seismic lines shown on Figure 11 were derived from a 3D seismic cube (30 m trace separation) coincident with the Progreso basin; obtained in 2010 by Petroamazonas. Although there is poor stratigraphic control on exploratory wells, a relatively good correlation 
of chronological markers (i.e. formation tops) were derived from well data (Petroamazonas confidential data and internal reports) and from facies analysis performed in the present work. Furthermore, the chronology of superficial reflections was constrained by the U-Pb ages presented here.

The seismic line W8 (Fig. 10A) is located in the south of the Peninsula and parallels the coastline coincident with site 1 . Although the quality of reflections is relatively poor, the seismic line is mainly divided into three main units. The lowermost unit may correspond to the Upper Cretaceous volcaniclastics deposits, the top of which is tentatively related to the angular unconformity roughly observed in the line and that may correspond to a décollement-surface. Above the unconformity, the Azúcar Formation consists of very chaotic high amplitude reflections with illegible geometries. The deformed series are bounded upwards by an angular unconformity interpreted to dip towards the south, as the Azúcar Formation reaches the surface $2 \mathrm{~km}$ towards the north of Line 1 at site 1 . The upper unit consist of less deformed sedimentary units located above the unconformity and attributed to the post accretionary series of the Ancón Group, the difference in deformation between the lower and upper series being similar to that observed in the field. The horizontal uppermost series are most probably of Quaternary age.

The NE-SW directed Line GS05 (Fig. 10B) is located in the westernmost part of the study area. It clearly displays two major thrust systems with a northeastward vergence formed by mostly parallel reflections. Deformation seems more pronounced towards the southern limit of the line, where closely-spaced highly dipping reflections may be related to thrust faults. The décollement level seems coincident with the major angular unconformity observed at approximately $1.5 \mathrm{~s}$ TWTT (two-way travel time), the local shallowing of reflectors at this surface most likely being artificial and related to velocity pull-ups. Well data constrained the 
location of the limit between the accretionary series and the Upper Cretaceous volcano-clastic deposits along the unconformity shown on seismic line GS05 (Aizprua et al., 2018).

The inlines 1780 and 1380 and the cross-line 2200 (Fig. 11) are located in the Progreso forearc basin and generally display: 1) a non-reflective zone related to the topographic and structural high related to the Estancia Hills; 2) a shallowing of reflectors towards both the SW and the NE basin limits and 3) a south-eastwards deepening of reflectors. In lines 1780, 1380 and 2200 the accretionary and post-accretionary series of the Azúcar Formation and the Ancón Group are related to thick high amplitude reflections showing little internal structure. They are limited upwards by a basin-scale high amplitude seismic marker defining a strong to moderate angular unconformity. Upwards, forearc basin infilling is related to several facies assemblages which are mostly defined by parallel reflections with moderate to high amplitude and high continuity reflectors. Early forearc series such as those of the Villingota and Dos Bocas Formations crop out near the OFH (Estancia Hills) and at the northwest basin border (cross-line 2200); otherwise they are covered by sediments younger than $16 \mathrm{Ma}$ (inlines 1780 and 1380; Fig. 11) as constrained by the age of sample CP405. Several angular unconformities are of local to regional character and are believed to be related to sea-level changes and in a lesser extent to fault activity, in concordance with field observations.

The seismic characteristics of the zone close to the Estancia Hills vary along strike. Along inline 1780 (Fig. 11A), a thick sigmoid package ( 1.5 s TWTT, two-way travel time; 5 $\mathrm{km}$ long) of mostly chaotic reflections lies unconformably above the units related to the Azúcar Formation and the Ancón Group We interpret these zones as debris-flows resulting from the onset of uplift of the Estancia Hills. Reflectors attributed to the Zapotal Formation are parallel equivalents of the non-reflective zone attributed to the debris flow (see also inline 1380). These 
aspects show that the Zapotal Formation is coeval with the onset of uplifting of the Estancia Hills, as suggested in the previous stratigraphic sections. The Zapotal Formation shows pervasive evidence of normal faulting, most of them being sealed down the upper limit of the group. In inline 1780 sedimentary units younger than the Zapotal Formation (e.g. younger than 32-30 Ma, see previous sections) are arranged in a more or less parallel way in the basin depocenter but show chaotic geometries next to the Estancia Hills, suggesting ongoing deformation at the topographic high. Along inline 1380 (Fig. 11B), next to the structural high, reflections are observed deeper than in inline 1780 and they appear less chaotic. Seismic reflectors located above the top of the Zapotal Formation systematically thin towards the topographic high, most likely defining syn-tectonic sedimentation and hence constant uplift of the Estancia Hills since 32-30 Ma, the age proposed in this work for the Zapotal Formation

The NE limit of the forearc basin is related to the Carrizal fault system. Inlines 1780 and 1380 show that the Carrizal fault system has followed an inversion period, which disrupted the basin floor. Inversion is related to uplifted growth sediments at the basin border and onlaping terminations basinwards. Onset of inversion is coeval with the onlaping reflections above the black dashed thin marker (Figs. 11A and 11B) and seems to be older than $\sim 16 \mathrm{Ma}$.

\section{DISCUSSION}

\subsection{The accretionary prism and the post-accretion series}

The compressional deformation observed at the Santa Elena Peninsula and the Playas high, beneath the depocenters of the Miocene Progreso basin and most likely beneath the 
Miocene-Quaternary Gulf of Guayaquil-Tumbes basins, define an accretionary prism (Fig. 12B). This definition is mostly related to the deformation style and the position of the fold-andthrust series between the active arc in the Western Cordillera and the trench. Besides the eventual loss of some parts of the prism via subduction-erosion processes, the current extension of this accretionary prism is considered as relatively local. Indeed, no coeval deformed series have been observed north of the Chongón-Colonche hills and further south in North Peru, where the older sediments of the modern forearc (i.e. the Salinas Formation) are younger than the Azúcar Formation (i.e. Early Eocene) and are significantly less deformed (Witt et al., 2018).

The Guayaquil Formation may contain the oldest sediments having a sialic composition in the entire Ecuadorian forearc (whole-rock geochemistry analysis; Witt et al., 2018); an aspect also evidenced by the presence of heavy minerals with continental affinity (Luzieux, 2007; Fig. 3). Nevertheless, although this could be tentatively defined as an early proximity of SW Ecuador to a continental magmatic arc, other aspects such as the presence of acid intrusions in the Pascuales area (e.g. north Guayaquil) may have resulted in the acid geochemistry of the Guayaquil Formation Regardless of the origin of the continental-like affinity of the Guayaquil Formation, the detrital character and deformation of the Paleocene Azúcar Formation recorded the main event related to the accretion of SW Ecuador against continental South America. Furthermore, the Azúcar Formation recorded the first metamorphic input as shown in their heavy mineral record (Fig. 3D; (Luzieux, 2007). The U-Pb ages presented here, in combination with former paleontological data, suggest that the accretion of SW Ecuador took place between 61 and 56 Ma. Thus, confirming (at least partially) former hypotheses that account for a multi-episodic construction of the Ecuadorian forearc basement 
through several accretion events (Hughes and Pilatasig, 2002; Jaillard et al., 2009; Kerr et al., 2002).

Both the Azúcar Formation and sediments in the Pacoa area are devoid of evidence of syn-sedimentary deformation, which suggests that construction of the accretionary prism occurred after $\sim 55 \mathrm{Ma}$ (Fig. 12B). This aspect is corroborated by the parallelism of deformed reflectors in seismic lines and by the presence of boulders of the Azúcar Formation in highly deformed series related to the accretionary prism (Fig. 4D), which confirms the post $\sim 55 \mathrm{Ma}$ age for the deformation (Figs. 4D and 4G). The high degree of deformation, the relative scarcity of outcrops and the poor quality of seismic reflections prevent a clear characterization of the internal geometry of the prism including its main vergence. Thus, strain directions seem to have rotated through time as evidenced by structural analysis of the Santa Elena Formation (Jaillard et al., 1997). Although a clear NE vergence may be defined in the westernmost parts of the Peninsula, to the SE, near site 1 the thrust vergence is not clear in the field or in seismic records. Formation of the accretionary prism may have raised deep sediments in concordance with the $>2000 \mathrm{~m}$ water depth depositional paleoenvironment proposed for some parts of the Azúcar Formation (Ordoñez et al., 2006). Although more evidence is required the highly penetrative deformed sediments observed near Ancón (Comp.Fig. 2B) may represent parts of an outer prism in which deformation was more assisted by fluids. Accretionary prisms are common features of the upper part of subduction zones. Based on the reviews of (Clift and Vannucchi (2004) and Noda (2016) the presence of an accretionary prism may result from a significant amount of sediments at the trench (excess of $\sim 1 \mathrm{~km}$ ) and a great convergence velocity (greater than $\sim 60 \mathrm{~mm} / \mathrm{yr}$ ). Nevertheless, the development of more local prisms is believed to result from other factors such as oblique convergence and terrane accretion. A new model for the formation of an accretionary wedge related to the Azúcar Formation has been 
recently proposed in new paleogeographic models for the evolution of SW Ecuador and NW Peru (Aizprua et al., 2018). Also, an accretionary-type model has been recently proposed for the evolution of the forearc of NW Peru (Espurt et al., 2018).

Up-section, deformation in the Ancón Group is mainly related to extensional tectonics (Fig. 12C), although small-scale compressional deformation has been observed in several locations (Fig. 6B). The syn-tectonic style characterized by mass-transport deposits, cliff-scale slump features and extensional faulting most likely defines gravity-driven structures (Fig. 6C). The presence of instability features and the absence of major compressional deformation suggest that the sedimentation of the Ancón Group occurred after the main period of formation of the accretionary prism. In this context and taking into account that $\mathrm{U}-\mathrm{Pb}$ ages for the Ancón Group are between $\sim 54$ and $\sim 40 \mathrm{Ma}$ it is suggested that the accretionary prism was active mainly between $\sim 55$ and $\sim 54 \mathrm{Ma}$ and that probably ongoing, but significantly weaker deformation characterized the prism from $\sim 54$ to $\sim 40$ Ma. Nevertheless, more efforts are needed to properly constraint the age of the base of the Ancón Group.

The accretion to post-accretion stages form a first depositional stage during which the basin was a turbiditic slope with currents mostly directed in a north south axis (Sites 1 to 3 ). The overall fining-upward deposits in this system, from the Azúcar Formation to the Ancón Group, marks a progressive decay of the southward tilting linked to the decrease of the activity of the accretionary prism. The final progradation of the slope fan leads to the build-up of a shelf margin where shallower deltaic systems develop as those observed in Sites 4 and 5 . Furthermore, the slope may have been directed westwards by the end of deposition of the Ancón Group (Jaillard et al., 1997). The provenance of these sediments is in strike relationship with the magmatic arc developed in the Western Cordillera (Witt et al., 2017). A comparison of 
the zircon record found in the Paleocene - Eocene sediments of the forearc and the age of intrusive arc-related bodies in the Cordillera may shed some light on detailed provenance aspects and should be considered in further studies.

\subsection{The outer forearc high}

The seaward part of accretionary active margins (accretionary forearcs) is often divided into two parts; the first one, an inner forearc basin usually showing flat-topped or low slope surfaces and related to depocenters evolving between the arc and the outer forearc high (OFH; a structural high usually coincident with the slope break) and the second one, the outer forearc system which is often coincident with the continental slope. From the earliest works dealing with forearc evolution the $\mathrm{OFH}$ was regarded as a major factor controlling the evolution of forearc areas (Dickinson and Seely, 1979). The strong control being simple in nature and related first to the rate at which the OFH rises and second to how the sedimentation rate can pace with it (Dickinson and Seely, 1979; Mitchell et al., 2010). Thus, the trapping of sediments at the inner forearc or the by-pass of sediments through the outer forearc and trench is a major aspect controlling the subduction regime and therefore the architecture of the outer margin. Nevertheless, with some remarkable exceptions as the Nankai accretionary margin in Japan (Moore et al., 2007; Takano et al., 2013; Buchs et al., 2015) or the Great Valley basin in USA (Mitchell et al., 2010) the relationships between the $\mathrm{OFH}$ and the forearc basin remain relatively unexplored. Shoaling sedimentation from bathyal or slope to shallow water environments has been observed in many forearc basins with most hypothesis suggesting driving factors ascribed to the uplift of the outer forearc high or to basal sediment accretion (Encinas et al., 2012; Buchs et al., 2015). 
The river and shallow water deposits of the Zapotal Formation are bounded to the west by the Estancia Hills (Fig. 12D). Evidence shown here constrain a compressional regime for the formation of the topographic high; they include: 1) the pervasive thinning of stratigraphic series towards the structural high; 2) the absence of normal faults near the structural high; 3) important erosion related to the presence of debris flows downlapping ancient reflections; 4) onlapping of the Zapotal Fm above the upper part of the debris flow and 5) the high degree of zircon recycling, as evidenced in Miocene series of the Villingota and Subibaja Formations. All of this evidence suggests the activity of a thrust fault, which may be related to the accretionary prism described in the previous sections, although not directly observed in seismic data. It is proposed in this work that the Estancia Hills acts as an outer forearc high $(\mathrm{OFH})$ separating the forearc basin to the west from the accretionary and post-accretionary series to the east (Fig. 12D). Uplift along this OFH may be important as deep rocks of the Upper Cretaceous volcaniclastics series (cherts of the Santa Elena Formation) crop out near the surface to the southwest of site 7 (Comp.Fig. 2N). The activity of the OFH seems pervasive during the Neogene as seismic records shows constant thinning of series younger than 32-30 Ma and no Oligocene or younger sediments are observed west of the OFH.

OFHs are crucial features in the evolution of trench-forearc systems. It is believed that formation of an $\mathrm{OFH}$ results in a landward increase of accommodation space (Moore et al., 2007; Buchs et al., 2015; Noda, 2016). The evolution of accretionary prims, as other types of fold-and-thrust belts, is controlled by the interaction between internal factors such as the slope of the basal décollement and the topographic surface (the addition of both being the taper), the strength of the materials forming the prism and the décollement and by external factors such as sedimentation and erosion. Thus, fold-and-thrust belts will grow by frontal accretion only when 
a critical taper is reached. When sedimentation modifies the taper angle deformation often migrates away from the deformation front in order to reconstitute a critical taper. This is the critical taper theory (Dahlen, 1990) extensively used during the last 50 years to analyse the evolution of fold-and-thrust belts. OFHs have been generally ascribed to out-of-sequence deformation (e.g. that resulting from a sub-critical taper in order to gain taper and return to growth by frontal accretion). It is difficult to clearly define what caused the $\mathrm{OFH}$ in $\mathrm{SW}$ Ecuador to be formed during Oligocene times, but a decrease of the taper angle, inferred here from 54 to $41 \mathrm{Ma}$ and probably subsequently related with a yet-to-be defined non-depositional step during 41-32 Ma may be an option, as no sedimentation has been observed for this period. The difficulty in defining the origin of the $\mathrm{OFH}$ in the wake of the accretionary prism comes first from the impossibility to clearly define the geometry of the prism and its vergence near the $\mathrm{OFH}$, the vergence of structures shown in Figure 12 being related to the clearest vergence observed between sites 3 and 5. Nevertheless, a relationship between the Estancia Hills and the activity of a deep thrust fault was already proposed in the early work of Benitez (1995).

Uplift along the OFH, caused the depositional locus to move eastwards (Figure 12E) with syn-tectonic growth strata on-laping former slope deposits. This is a mechanism very similar to that observed in other forearc - OFH assemblages, such as the Great Valley Basin (USA; Mitchell et al., 2010) and the Kumano basin (Japan; Moore et al., 2015; Takano et al., 2013). The direction of the OFH probably changed trough time, as extensional and strike slip systems affected the zone during the opening of the GGTB during Miocene to Quaternary times (Witt et al., 2006; Witt and Bourgois, 2010). In any case, based in our knowledge, the Estancia Hill may correspond to one of the best preserved exposures of an ancient outer forearc high worldwide. 


\subsection{The shallow-water forearc basin infilling}

As in other forearc basins related to the formation of an $\mathrm{OFH}$, the Progreso basin depocenter consists of shallow water sediments lying unconformably on deep slope sediments. The onset of the basin resulted from the definite rise of the $\mathrm{OFH}$, isolating the semi-enclosed triangular Progreso basin (protected bay) which fills up mainly with shallow marine sediments (Fig. 12E), whereas the Peninsula area may have been emerged ever since. The OFH remains stable during the entire basin evolution from $\sim 32$ to $\sim 10 \mathrm{Ma}$, as there is no evidence of basin dissection and outcrops of Oligocene - Miocene deposits in the Peninsula area.

The protected geographic configuration produced by the OFH favours the development of tidal dynamics, which is recorded for the first time in the Subibaja Formation (site 10) at 16 Ma. The tidal currents running through the Progreso Basin would then have been trending WNW-ESE. Owing to the likelihood that the north-western boundary of this basin (i.e. Chongón-Colonche Hills) was already uplifted, the tides might have entered in the basin from the east (Guayas area). Depending on the local configuration and systems tracts, either flood currents (to the WNW, ex. within channels) or ebb currents (to the ESE, ex. within sand bars) would have dominate. Open coast shoreline deposits might still have existed at this time (e.g. site 10). During the Progreso Formation, the tectonic quiescence of the basin brings about a decrease of the coarse clastic supply, favouring the onset of a carbonate system where oyster patch reefs develop close to the shoreline (site 12). Although the sedimentary evidence points to forced regression periods a thorough examination of forearc sedimentation in the wake of the eustatic variations during the last $30 \mathrm{Ma}$ is difficult to achieve as field evidence is sparse and the early period of the forearc basin evolution comprised between 30 and $16 \mathrm{Ma}$ has not been 
yet dated accurately, because of absence of primary zircons. The necessary accommodation for the deposition of the $2-3 \mathrm{~km}$ forearc sediments may have resulted from the formation of the OFH (a process suggested for other forearc basins) although the south-eastwards deepening of reflectors may also attest for an increase of subsidence towards the Gulf of Guayaquil-Tumbes basin, which opening period may have started and clear tidal dynamics reached at least in Quaternary times (Reynaud et al., 2018). The sedimentary succession in the upper part of the Progreso basin looks similar to that of other forearc Andean embayments, as those observed in the Valdivia complex in Chile (le Roux and Elgueta, 2000).

The Progreso basin records at least one episode of tectonic inversion as evidenced by the shallowing of reflectors at the Carrizal fault system (structural limit between the ChongónColonche Hills and the Progreso basin). Seismic evidence suggest that the main tectonic inversion step took place before $\sim 16 \mathrm{Ma}$ (Fig. 11B), the basin floor was probably flatter before the inversion. Although, more work is needed to constrain the timing of uplift of the ChongónColonche Hills and its eventual relationships with the sedimentary input in the Peninsula and Progreso basin, it seems reasonable that topographic growth in the hills is probably linked with the recycled zircon component from 30 to $16 \mathrm{Ma}$ in the basin; the hills acting as a semiregional topographic barrier preventing direct sourcing from Andean derived primary zircons. Moreover, this process was of lesser importance or inexistent in the westernmost sections of the hills (Montañita area; site 8) where primary 23 Ma zircons are present.

\section{Conclusions}


The SW of Ecuador exposes a Paleocene to Upper Miocene accretionary, postaccretionary and forearc basin system. Youngest age clusters obtained by LA ICP-MS U-Pb dating on detrital zircon indicate the age of sedimentation, thus outlining the importance of the $\mathrm{U}-\mathrm{Pb}$ method on zircon for dating sediments that are, at least in part, derived from active volcanic arcs.

Sedimentary and seismic-derived tectonic analysis as well as detrital zircon dating on the Paleocene Azúcar Formation indicates that SW Ecuador represents an oceanic block accreted against the continental margin between 61 and 55 Ma. The Azúcar Formation and coeval deposits located near the Chongón-Colonche Hills were deposited prior to the formation of a complex and regional fold-and-thrust belt system that defines an accretionary prism, whose main activity may have taken place between 55 and 54 Ma. The Ancón Group, the post accretionary series, deposited from $\sim 54 \mathrm{Ma}$ to $\sim 40 \mathrm{Ma}$ and shows pervasive normal faulting and gravitational deposits related to slope instabilities, suggesting a significant decrease of the activity of the accretionary prism. The Azúcar Formation would correspond to the junction of a steepening submarine slope with a basin floor fan (large conglomeratic channels and coarsegrained turbidites). Then, the Ancón Group would record the progressively finer grained turbidites of a slope fan, finally undergoing to mass-transport (mud-dominated turbidites and mass-transport complexes). The transition from the Azúcar Formation to the Ancón Group is denoted by a significant decrease of the topographic profile resulting in shallowing upwards sedimentary series.

The structural high of the Estancia Hills shows Late Cretaceous to Eocene rocks at surface levels. It is characterized in seismic records by debris flows downlapping older and deeper sedimentary units and by continental to shallow water sediments unconformably 
covering those debris flows. Thus, the degree of zircon recycling is manifestly higher next to the structural high. It is proposed in this work that the structural high defines an outer forearc high (OFH), typical of forearc basin such as those observed in the Kumano (Japan) and Great Valley (USA) basins. The evolution of the $\mathrm{OFH}$ is most likely related to the uplift of a thrust slice during 32-30 Ma, coeval with deposition of the coarse-grained shallow-water to continental Zapotal Formation. Evidence presented here suggest the existence of a stable outer forearc high limiting the forearc depocenter for at least $20 \mathrm{Ma}$ and creating the necessary accommodation for a $\sim 3 \mathrm{~km}$ thick forearc sedimentary package. The forearc sediments are related to shallow water environments (Formations Dos Bocas, Villingota, Subibaja and Progreso) ranging from littoral to tidal facies most likely related to a triangular protected bay that mimics the architecture of the forearc depocenter. The youngest sediments dated here belong to the Progreso Formation and yielded a $\sim 10$ Ma age.

\section{Acknowledgements}

We would like to thank Petroamazonas, and especially Manuel Rivera for letting us to publish the seismic material. Patrice Baby, Galo Montenegro and Nelson Jimenez are kindly thanked for helpful discussions in the field. Reviews of A. Noda and G. Moore were very appreciated and improved the quality of this paper. This work was found by Petroamazonas (Ecuadorian Petroleum Company) and INSU (Institut National de Sciences de l'Univers, France).

\section{References}


Aizprua, C., Witt, C., Reynaud, J.Y. 2018. Tectono-stratigraphic evolution along a trench-linked sheared margin: Gulf of Guayaquil-Tumbes basin, Northern Andes, Ecuador-Peru. Réunion Sciences de la Terre, 22-26 Octobre, Lille, France.

Benitez, S., 1995. Evolution géodynamique de la province côtière sud-équatorienne au Crétacé supérieur-Tertiaire. PhD thesis. Université Joseph-Fourier-Grenoble I. 237 p.

Bourgois, J., Bigot-Cormier, F., Bourles, D., Braucher, R., Dauteuil, O., Witt, C., Michaud, F., 2007. Tectonic record of strain buildup and abrupt coseismic stress release across the northwestern Peru coastal plain, shelf, and continental slope during the past 200 kyr. Journal of Geophysical Research: Solid Earth 112, B04104.

Bristow, C.R., 1975. On the age of the Zapotal Sands of Southwest Ecuador. Newsletters on Stratigraphy $119-134$.

Buchs, D.M., Cukur, D., Masago, H., Garbe-Schönberg, D., 2015. Sediment flow routing during formation of forearc basins: constraints from integrated analysis of detrital pyroxenes and stratigraphy in the Kumano Basin, Japan. Earth and Planetary Science Letters 414, 164-175.

Cawood, P.A., Hawkesworth, C., Dhuime, B., 2012. Detrital zircon record and tectonic setting. Geology 40, 875-878.

Clift, P., Vannucchi, P., 2004. Controls on tectonic accretion versus erosion in subduction zones: Implications for the origin and recycling of the continental crust. Reviews of Geophysics 42, 2

Clift, P.D., Hartley, A.J., 2007. Slow rates of subduction erosion and coastal underplating along the Andean margin of Chile and Peru. Geology 35, 503-506.

Collot, J., Charvis, P., Gutscher, M., Operto, S., 2002. Exploring the Ecuador-Colombia active margin and interplate seismogenic zone. EOS, Transactions American Geophysical Union 83, 185 190.

Dahlen, F.A., 1990. Critical Taper Model of Fold-And-Thrust Belts and Accretionary Wedges. Annual Review of Earth and Planetary Sciences 18, 55-99.

Daly, M.C., 1989. Correlations between Nazca/Farallon Plate kinematics and forearc basin evolution in Ecuador. Tectonics 8, 769-790. 
Dickinson, W., Seely, D., 1979. Structure and stratigraphy of forearc regions. American Association of Petroleum Geologist Bulletin 63, 2-31.

Dickinson, W.R., Gehrels, G.E., 2009. Use of U-Pb ages of detrital zircons to infer maximum depositional ages of strata: A test against a Colorado Plateau Mesozoic database. Earth and Planetary Science Letters 288, 115-125.

Einsele, G., Liu, B., Dürr, S., Frisch, W., Liu, G., Luterbacher, H.P., Ratschbacher, L., Ricken, W., Wendt, J., Wetzel, A., Yu, G., Zheng, H., 1994. The Xigaze forearc basin: evolution and facies architecture (Cretaceous, Tibet). Sedimentary Geology 90, 1-32.

Encinas, A., Finger, K.L., Buatois, L.A., Peterson, D.E., 2012. Major forearc subsidence and deepmarine Miocene sedimentation in the present Coastal Cordillera and Longitudinal Depression of south-central Chile $\left(38^{\circ} 30^{\prime} \mathrm{S}-41^{\circ} 45^{\prime} \mathrm{S}\right)$. Geological Society of America Bulletin 124,1262 1277.

Espurt, N., Brusset, S., Baby, P., Henry, P., Vega, M., Calderon, Y., Ramirez, L., and Saillard, M., 2018, Deciphering the Late Cretaceous-Cenozoic Structural Evolution of the North Peruvian Forearc System: Tectonics, v. 37, p. 251-282.

Feininger, T., 1987. Allochthonous terranes in the Andes of Ecuador and northwestern Peru. Canadian Journal of Earth Sciences 24, 266-278.

Gehrels, G., 2014. Detrital zircon U-Pb geochronology applied to tectonics. Annual Review of Earth and Planetary Sciences 42, 127-149.

Hall, M.L., Calle, J., 1982. Geochronological control for the main tectonic-magmatic events of Ecuador. Earth-Science Reviews 18, 215-239.

Handschumacher, D.W., 1976. Post-Eocene Plate Tectonics of the Eastern Pacific. The geophysics of the Pacific Ocean Basin and its margin, 19, 177-202

Hey, R., 1977. Tectonic evolution of the Cocos-Nazca spreading center. Geological Society of America Bulletin 88, 12.

Hughes, R.A., Pilatasig, L.F., 2002. Cretaceous and Tertiary terrane accretion in the Cordillera Occidental of the Andes of Ecuador. Tectonophysics 345, 29-48. 
Jaillard, E., Lapierre, H., Ordonez, M., Alava, J.T., Amortegui, A., Vanmelle, J., 2009. Accreted oceanic terranes in Ecuador: southern edge of the Caribbean Plate? Geological Society, London, Special Publications 328, 469-485.

Jaillard, E., Benitez, S., Mascle, G.H., 1997. Les déformations paléogènes de la zone d'avant-arc sudéquatorienne en relation avec l'évolution géodynamique. Bulletin de la Société Géologique de France. 168, 403-412.

Jaillard, E., Ordoñez, M., Benitez, S., Berrones, G., Jiménez, N., Montenegro, G., Zambrano, I., 1995. Basin development in an accretionary, oceanic-floored fore-arc setting: southern coastal Ecuador during late Cretaceous-late Eocene time. in Tankard, A.J., Suarez, S.R.,and Welsink, H.J., eds., Petroleum Basins of South America: American Association of Petroleum Geologists Memoir 62, p. 615-631

Jarrard, R.D., 1986. Terrane motion by strike-slip faulting of forearc slivers. Geology 14, 780-783.

Kerr, A.C., Aspden, J.A., Tarney, J., PILATASIG, L.F., 2002. The nature and provenance of accreted oceanic terranes in western Ecuador: geochemical and tectonic constraints. Journal of the Geological Society 159, 577-594.

le Roux, J.P., Elgueta, S., 2000. Sedimentologic development of a Late Oligocene-Miocene forearc embayment, Valdivia Basin Complex, southern Chile. Sedimentary Geology 130, 27-44. https://doi.org/10.1016/S0037-0738(99)00096-2

Ludwig, K.R., 2012, Isoplot 3.75: A Geochronological Toolkit for Microsoft Excel: Berkeley Geochronology Center Special Publication, v. 5, 75 p.

Luzieux, L., Heller, F., Spikings, R., Vallejo, C., Winkler, W., 2006. Origin and Cretaceous tectonic history of the coastal Ecuadorian forearc between $1 \mathrm{~N}$ and $3 \mathrm{~S}$ : Paleomagnetic, radiometric and fossil evidence. Earth and Planetary Science Letters 249, 400-414.

Luzieux, L., 2007. Origin and late Cretaceous-Tertiary evolution of the Ecuadorian forearc. PhD thesis, ETH, Zurich. 196 p.

Manzotti, P., Poujol, M., Ballèvre, M., 2015. Detrital zircon geochronology in blueschist-facies metaconglomerates from the Western Alps: implications for the late Carboniferous to early Permian palaeogeography. International Journal of Earth Sciences 104, 703-731. 
Melnick, D., Echtler, H.P., 2006. Inversion of forearc basins in south-central Chile caused by rapid glacial age trench fill. Geology 34, 709-712.

Michaud, F., Witt, C., Royer, J.-Y., 2009. Influence of the subduction of the Carnegie volcanic ridge on Ecuadorian geology: Reality and fiction. Geological Society of America Memoirs 204, $217-228$.

Mitchell, C., Graham, S.A., Suek, D.H., 2010. Subduction complex uplift and exhumation and its influence on Maastrichtian forearc stratigraphy in the Great Valley Basin, northern San Joaquin Valley, California. Geological Society of America Bulletin 122, 2063-2078.

Moore, G.F., Bangs, N.L., Taira, A., Kuramoto, S., Pangborn, E., Tobin, H.J., 2007. ThreeDimensional Splay Fault Geometry and Implications for Tsunami Generation. Science 318, $1128-1131$

Moore, G.F., Boston, B.B., Strasser, M., Underwood, M.B., Ratliff, R.A., 2015. Evolution of tectonosedimentary systems in the Kumano Basin, Nankai Trough forearc. Marine and Petroleum Geology 67, 604-616.

Moxon, I.W., Graham, S.A., 1992. History and controls of subsidence in the Late Cretaceous-Tertiary Great Valley forearc basin, California. Geology, 15, 626-629.

Noda, A., 2016. Forearc basins: Types, geometries, and relationships to subduction zone dynamics. Geological Society of America Bulletin 128, 879-895. https://doi.org/10.1130/B31345.1

Noda, A., TuZino, T., 2007. Characteristics of sediments and their dispersal systems along the shelf and slope of an active forearc margin, eastern Hokkaido, northern Japan. Sedimentary Geology 201, 341-364.

Ordoñez, M., Jiménez, N., and Suarez, J., 2006. Micropaleontología Ecuatoriana. Petroproducción. Centro de Investigaciones Geológicas Guayaquil. 634p.

Paquette, J.-L., Piro, J.-L., Devidal, J.-L., Bosse, V., Didier, A., Sannac, S., Abdelnour, Y., 2014. Sensitivity Enhancement in LA-ICP-MS by N2 Addition to Carrier Gas: Application to Radiometric Dating of U-Th-Bearing Minerals. Agilent ICP-MS Journal 58, 4-5.

Pedoja, K., Dumont, J.-F., Lamothe, M., Ortlieb, L., Collot, J.-Y., Ghaleb, B., Auclair, M., Alvarez, V., Labrousse, B., 2006. Plio-Quaternary uplift of the Manta Peninsula and La Plata Island 
and the subduction of the Carnegie Ridge, central coast of Ecuador. Journal of South American Earth Sciences 22, 1-21.

Pedoja, K., Husson, L., Johnson, M.E., Melnick, D., Witt, C., Pochat, S., Nexer, M., Delcaillau, B., Pinegina, T., Poprawski, Y., 2014. Coastal staircase sequences reflecting sea-level oscillations and tectonic uplift during the Quaternary and Neogene. Earth-Science Reviews 132, 13-38.

Regalla, C., Kirby, E., Fisher, D., Bierman, P., 2013. Active forearc shortening in Tohoku, Japan: Constraints on fault geometry from erosion rates and fluvial longitudinal profiles. Geomorphology 195, 84-98.

Reynaud, J.-Y., Witt, C., Pazmiño, A., Gilces, S., 2018. Tide-dominated deltas in active margin basins: Insights from the Guayas estuary, Gulf of Guayaquil, Ecuador. Marine Geology 403, 165-178. https://doi.org/10.1016/j.margeo.2018.06.002

Sage, F., Collot, J.-Y., Ranero, C., 2006. Interplate patchiness and subduction-erosion mechanisms: Evidence from depth-migrated seismic images at the central Ecuador convergent margin. Geology 34, 997-1000.

Schoene, B., 2014. U-Th-Pb geochronology. Treatise on geochemistry 4, 341-378.

Schütte, P., Chiaradia, M., Beate, B., 2010. Geodynamic controls on Tertiary arc magmatism in Ecuador: Constraints from U-Pb zircon geochronology of Oligocene-Miocene intrusions and regional age distribution trends. Tectonophysics 489, 159-176.

Takano, O., Itoh, Y., Kusumoto, S., 2013. Variation in forearc basin configuration and basin-filling depositional systems as a function of trench slope break development and strike-slip movement: examples from the Cenozoic Ishikari- Sanriku-Oki and Tokai-Oki- KumanoNada forearc basins, Japan. Mechanism of sedimentary basin formation-multidisciplinary approach on active plate margins. InTech, Rijeka (Croatia).

Tanaka, Y., Abella, J., Aguirre-Fernández, G., Gregori, M., Fordyce, R.E., 2017. A new tropical Oligocene dolphin from Montañita/Olón, Santa Elena, Ecuador. PLOS ONE 12, e0188380.

Vallejo, C., Winkler, W., Spikings, R.A., Luzieux, L., Heller, F., Bussy, F., 2009. Mode and timing of terrane accretion in the forearc of the Andes in Ecuador. Geological Society of America Memoirs 204, 197-216. 
Walker, R.G., 1976. Facies Models 2. Turbidites and Associated Coarse Clastic Deposits. Geosciences Canada 3.

Witt, C., Bourgois, J., 2010. Forearc basin formation in the tectonic wake of a collision-driven, coastwise migrating crustal block: The example of the North Andean block and the extensional Gulf of Guayaquil-Tumbes Basin (Ecuador-Peru border area). Geological Society of America Bulletin 122, 89-108.

Witt, C., Bourgois, J., Michaud, F., Ordoñez, M., Jiménez, N., Sosson, M., 2006. Development of the Gulf of Guayaquil (Ecuador) during the Quaternary as an effect of the North Andean block tectonic escape. Tectonics 25, 3, TC3017

Witt, C., Rivadeneira, M., Poujol, M., Barba, D., Beida, D., Beseme, G., Montenegro, G., 2017. Tracking ancient magmatism and Cenozoic topographic growth within the Northern Andes forearc: Constraints from detrital U-Pb zircon ages. Geological Society of America Bulletin $129,415-428$.

Witt, C., Aizprua, C., Reynaud, J.Y, Poujol, M., Amberg. C., 2018. An U-Pb zircon chronology based correlation for forearc sediments trough the Ecuadorian - Peruvian border. Réunion Sciences de la Terre, 22-26 Octobre, Lille, France.

Xie, X., Heller, P.L., 2009. Plate tectonics and basin subsidence history. Geological Society of America Bulletin 121, 55-64.

\section{Figure captions}

Figure 1. Geodynamic sketch of the Andes of Central-South Ecuador and North Peru including the forearc area. The rectangle shows location of the studied zone shown in detail in Figure 2. GGTB, Gulf of Guayaquil-Tumbes Basin. Topography and bathymetry from GeomapAPP. 
(http://www.geomapapp.org/). Offshore structures in the GGTB compiled from Witt and Bourgois (2010).

Figure 2. The SW Ecuadorian forearc. A) SRTM-derived topography showing geologic features, main localities (crosses) and sites discussed in the text (black dots). CFS, Carrizales Fault System; LCF, La Cruz Fault. Localities abbreviations are as follows: A, Ancón; B, Ballenita; LJ, Las Juntas; M, Montañita; P, Progreso; PL, Playas; PS, Posorja; S, Salinas; Z, Zacachun. B) Geological map modified from the 2017 1:1000000 Inigemm Map including sample location. Black circles are U-Pb zircon ages first published in Witt et al. (2017). White circles represent new analysis.

Figure 3. Stratigraphy, age constraints and sediment depositional environment in SW Ecuador. A) Schematic stratigraphic column showing main litho-tectonic units. Thickness of the column does not reflect true sediment thickness. B) U-Pb zircon youngest ages for all samples shown on Figure 2B; including those published in Witt et al. (2017). Ages in white rectangles represent the age of sedimentation. Black rectangles are ages most likely coming from recycled rocks or zircons. C) Sedimentary environment at time of deposition obtained from paleontological records (Ordoñez et al., 2006). Abbreviations are explained on the legend. D) Heavy mineral associations obtained from Luzieux (2007).

Figure 4. The Azúcar Formation A) Flysh-like deep series. B) Slope deposits showing flat-base sandstones and fine conglomerates, location of CP007 sample. C) Large conglomerate channel incised in sandstones, location of CP006 sample. D) Boulder of the Azúcar Formation (sample CP107) obtained from a debris-flow near La Libertad locality. E to G) Tera-Wasserburg concordias showing the youngest dates obtained from sediments of the Azúcar Formation 
(location of samples on Figure 2B and Table 1). Dates used for age calculations are shown with thicker black lines. Additional figures shown in Comp.Fig. 2A to 1D.

Figure 5. Outcrop near the Pacoa locality at site 3. A) General view of the folded outcrop showing the reference tuffaceous layer at the left and the right of the picture. B) Slightly overturned series at the north flank of the antiform showing the reworked tuffaceous layer. C) The southern part of the anticline showing the tuffaceous layer and location of sampling. Age constrains shown in Comp.Fig. 2E.

Figure 6. Outcrops of the Ancón Group in the cliffs of Ancón (site 4), Ballenita (site 5) and Anconsito (site 6) areas. A) Sandstone channels incising the debris flows. B) Reverse fault and location of sample CP014. C) Extensional syn-tectonic faulting, the layer defined by the dashed line seal the deformation. D) Channel incision above a massive olistolith-bearing sandstone. E) Flaky lignite-rich layers. F) Deltaic plane channel-bars at the top of the succession at site 6. G to I) Tera-Wasserburg concordias showing the youngest dates obtained from sediments of the Ancón Group (location of samples on Figure 2B). Dates used for age calculations are shown with thicker black lines. Additional figures shown in Comp.Fig. 2F to $1 \mathrm{M}$.

Figure 7. A) Conglomeratic facies of the Zapotal Formation at the locality type near the Estancia Hills at site 7. B) Volcanic-rich clastic deposits of the Zapotal Fm, location of sample CP018. C, D) Tera-Wasserburg concordias showing the youngest dates obtained from sediments of the Zapotal Formation. Dates used for age calculations are shown with thicker black lines. Additional figures shown in Comp.Fig. $2 \mathrm{~N}$ to $1 \mathrm{P}$. 
Figure 8. A) Yellowish litharenites and sandstones (Dos Bocas Formation) bounded by low angle unconformites. Additional pictures of this outcrop are shown in Com.Fig.1Q and 1R. B) White sandstones of the Dos Bocas Formation C) U-Pb dating performed on sample CP705 D, E) Recycled zircon component of Lower-Middle Miocene sedimentary rocks cropping out near the Estancia Hills; major peaks are related to the Zapotal Formation ( 30 Ma), Ancon Group ( 43 Ma) and Azúcar Formation ( 60 Ma). An additional histogram related to the same recycled component is shown in Com.Fig.1P.

Figure 9. The Neogene infilling of the Progreso forearc basin. A) White tuffaceous sandstones of the Subibaja Formation. B) Littoral deposits of the limit between the Subibaja and Progreso formations, location of samples CP207 and CP402. C) Tidal deposits of the Subibaja Formation and ophiomorpha sp. D) Oyster patches and muddy calcarenites typical of the Progreso Formation E, F) Age spectra of youngest zircons of the Subibaja and Progreso formations.

Figure 10. Time migrated seismic lines of key sections of the accretionary prism. Location of lines in Figure 2A. A) NW-SE directed line W8 showing the main unconformity between the Azúcar Formation (accretionary series) and the Ancón Group (post-accretionary series). B) NESW directed line GS05 showing the main thrust and fold systems near the Pacoa area (site S3). Note the difference between the scale of local observations performed in the field compared with the regional distribution of tectonic structures and sedimentary units observed in seismic lines.

Figure 11. Time migrated seismic lines and line drawing of key sections of the Progreso basin and its related outer forearc high $(\mathrm{OFH})$ coincident with the Estancia Hills. Location of lines in 
Figure 2A. A) Inline 1780 showing debris flow deposits that are believed to represent the first products resulting from the erosion of the OFH. B) Inline 1380 showing slight thickness variations of reflectors near the OFH suggest a long-lived and continuous uplift along the high. Note the down-lapping reflectors (DL) of the Zapotal Formation next to the structural high. C) Cross-line 2200 showing the southwards deepening of reflectors. Note that the displacement along normal faults is only partially related to the SE basin deepening.

Figure 12. A to E) Schematic cartoons showing the evolution of the Peninsula and Progreso Basin. Sections are related to the architecture observed in a NE-SW direction near the center of the Progreso basin. Sections are not balanced and are used here only for qualitative schematic purposes, this includes the vergence of thrust-fold systems and the frontal/basal accretionary processes taking place at the very front of the system. DB, debris flow; EH, Estancia Hills; $\mathrm{OFH}$, outer forearc high; PB, Progreso basin. 
Table 1. Sample information. All tuffs are reworked tuffs. The calculated age correspond to the weighted average age (Ludwig. 1991) obtained from the youngest zircon family. N.D = non defined

\begin{tabular}{|c|c|c|c|c|c|c|}
\hline Sample & Formation & Lithology & Lat $\left({ }^{\circ} \mathbf{S}\right)$ & Long $\left({ }^{\circ} \mathbf{W}\right)$ & \begin{tabular}{|c|} 
Youngest cluster \\
TW Concordia $(\mathrm{Ma})$
\end{tabular} & $\begin{array}{c}\text { Younger cluster } \\
\text { Weighted average (Ma) }\end{array}$ \\
\hline CP007 & Azúcar & Sandstone & $2^{\circ} 38^{\prime} 25.74^{\prime \prime}$ & $80^{\circ} 26^{\prime} 1.92^{\prime \prime}$ & $61.2 \pm 2.0(\mathrm{~N}=3)$ & $60.7 \pm 0.6(\mathrm{~N}=10)$ \\
\hline CP006 & Azúcar & Sandstone & $2^{\circ} 37^{\prime} 49.22^{\prime \prime}$ & $80^{\circ} 26^{\prime} 53.79^{\prime \prime}$ & $61.3 \pm 0.7(\mathrm{~N}=35)$ & $59.9 \pm 0.3(\mathrm{~N}=42)$ \\
\hline CP103 & Azúcar & Sandstone & $2^{\circ} 14^{\prime} 31.82^{\prime \prime}$ & $80^{\circ} 33^{\prime} 25.52^{\prime \prime}$ & $57.1 \pm 1.2(\mathrm{~N}=5)$ & $57 \pm 1.3(\mathrm{~N}=7)$ \\
\hline CP107 & Azúcar & Sandstone & $2^{\circ} 13^{\prime} 13.91^{\prime \prime}$ & $80^{\circ} 54^{\prime} 55.73^{\prime \prime}$ & $55.2 \pm 1.6(\mathrm{~N}=3)$ & $57.5 \pm 1.3(\mathrm{~N}=7)$ \\
\hline $\mathrm{CP} 212$ & N.D & Tuff & $2^{\circ} 6 ' 53.33^{\prime \prime}$ & $80^{\circ} 44^{\prime} 30.18^{\prime \prime}$ & $52.8 \pm 1.3(\mathrm{~N}=4)$ & $53.7 \pm 1.4(\mathrm{~N}=7)$ \\
\hline CP014 & Ancón & Sandstone & $2^{\circ} 22^{\prime} 44.23^{\prime \prime}$ & $80^{\circ} 47^{\prime} 47.60^{\prime \prime}$ & $54.5 \pm 1.9(\mathrm{~N}=3)$ & $53.4 \pm 1.1(\mathrm{~N}=4)$ \\
\hline CP017 & Ancón & Tuff & $2^{\circ} 9^{\prime} 28.19^{\prime \prime}$ & $80^{\circ} 46^{\prime} 48.85^{\prime \prime}$ & $48.6 \pm 0.6(\mathrm{~N}=6)$ & $48.5 \pm 1(\mathrm{~N}=6)$ \\
\hline CP010 & Ancón & Sandstone & $2^{\circ} 20^{\prime} 13.24^{\prime \prime}$ & $80^{\circ} 53^{\prime} 25.85^{\prime \prime}$ & $40.9 \pm 0.5(\mathrm{~N}=4)$ & $40.9 \pm 0.4(\mathrm{~N}=5)$ \\
\hline CP011 & Ancon & Tuff & $2^{\circ} 19^{\prime} 58.10^{\prime \prime}$ & $80^{\circ} 53^{\prime} 25.92^{\prime \prime}$ & $40.5 \pm 0.6(\mathrm{~N}=4)$ & $40.5 \pm 0.5(\mathrm{~N}=4)$ \\
\hline $\mathrm{CP} 018$ & Zapotal & Tuff & $2^{\circ} 19^{\prime} 11.25^{\prime \prime}$ & $80^{\circ} 32^{\prime} 54.32^{\prime \prime}$ & $32.5 \pm 0.3(\mathrm{~N}=4)$ & $32.5 \pm 0.3(\mathrm{~N}=10)$ \\
\hline CP218 & Zapotal & Sandstone & $2^{\circ} 44^{\prime} 27.03^{\prime}$ & $80^{\circ} 13^{\prime} 13.73^{\prime \prime}$ & $29.5 \pm 0.4(\mathrm{~N}=5)$ & $29.5 \pm 0.4(\mathrm{~N}=15)$ \\
\hline CP705 & Dos Bocas & Sandstone & $1^{\circ} 49^{\prime} 8.74^{\prime \prime}$ & $80^{\circ} 45^{\prime} 32.40^{\prime \prime}$ & $23.5 \pm 0.4(\mathrm{~N}=3)$ & $22.9 \pm 0.6(\mathrm{~N}=8)$ \\
\hline CP702 & Dos Bocas & Tuff & $2^{\circ} 13^{\prime} 2.40^{\prime \prime}$ & $80^{\circ} 34^{\prime} 22.17^{\prime \prime}$ & recycled & recycled \\
\hline CP019 & Villingota & Tuff & $2^{\circ} 22^{\prime} 17.04^{\prime}$ & $80^{\circ} 27^{\prime} 50.84^{\prime \prime}$ & recycled & recycled \\
\hline CP021 & Subibaja & Sandston & $2^{\circ} 23^{\prime} 8.33^{\prime \prime}$ & $80^{\circ} 26^{\prime} 8.24 "$ & recycled & recycled \\
\hline CP405 & Subibaja & Tuff & $2^{\circ} 11^{\prime} 40.41^{\prime}$ & $80^{\circ} 26^{\prime} 55.16^{\prime \prime}$ & $15.6 \pm 0.2(\mathrm{~N}=7)$ & $15.9 \pm 0.27(\mathrm{~N}=11)$ \\
\hline CP207 & Subibaja & Sandstone & $2^{\circ} 12^{\prime} 24.41^{\prime \prime}$ & $80^{\circ} 19^{\prime} 9.38^{\prime \prime}$ & $14.2 \pm 0.2(\mathrm{~N}=11)$ & $14.3 \pm 0.31(\mathrm{~N}=13)$ \\
\hline $\mathrm{CP} 402$ & Subibaja & Sandstone & $2^{\circ} 12^{\prime} 28.45^{\prime \prime}$ & $80^{\circ} 19^{\prime} 10.22$ & $14.3 \pm 0.1(\mathrm{~N}=36)$ & $14.2 \pm 0.12(\mathrm{~N}=50)$ \\
\hline CP022 & Progreso & Sandstone & $2^{\circ} 24^{\prime} 29.29^{\prime}$ & $80^{\circ} 22^{\prime} 22.69^{\prime \prime}$ & subconcordant & $\sim 11.5$ (two grains) \\
\hline CP023 & Progreso & Tuff & $2^{\circ} 24^{\prime} 29.29^{\prime}$ & $80^{\circ} 22^{\prime} 22.69^{\prime \prime}$ & $10.3 \pm 0.2(\mathrm{~N}=3)$ & $10.2 \pm 0.41(\mathrm{~N}=5)$ \\
\hline
\end{tabular}




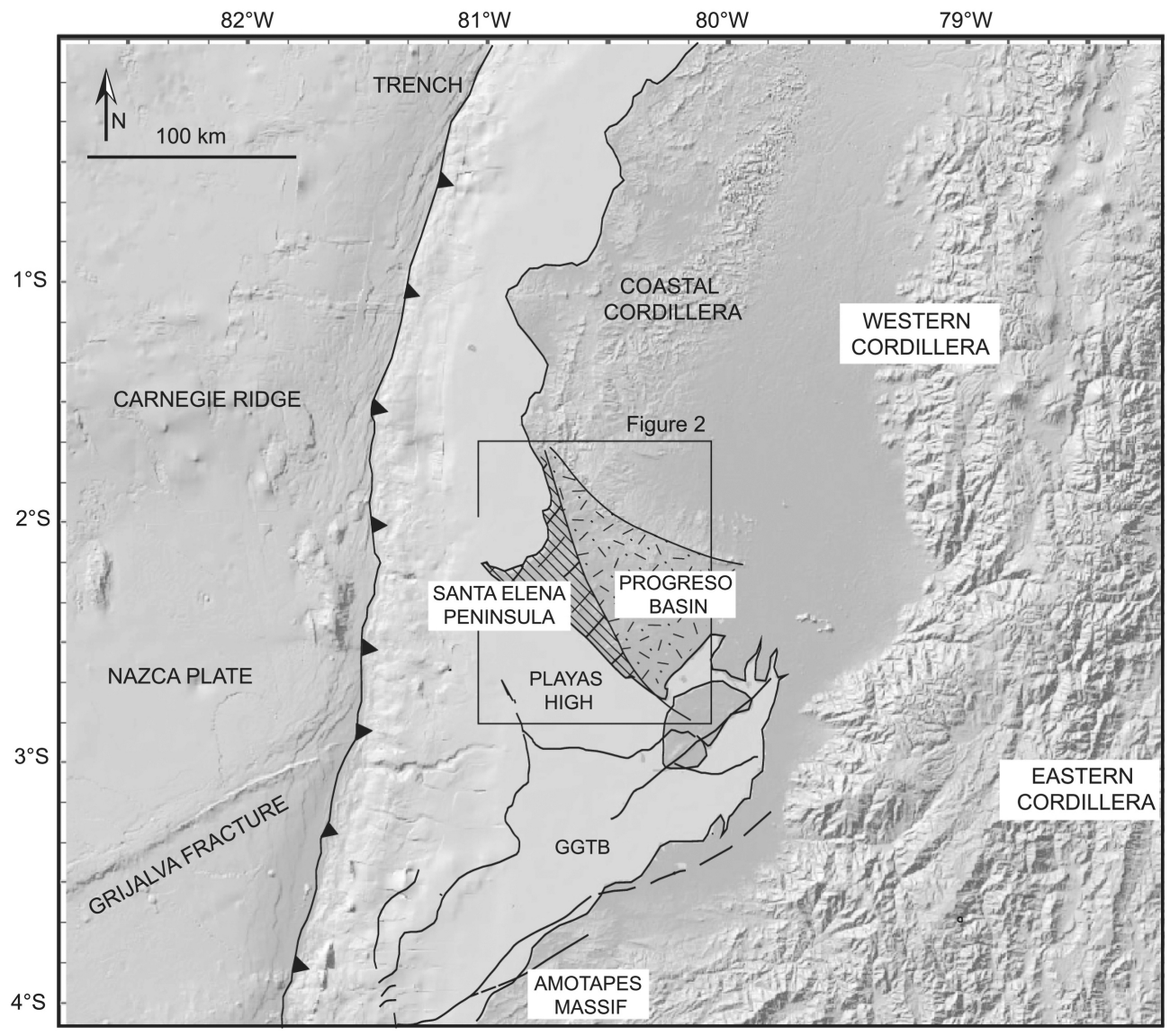

Figure 1 


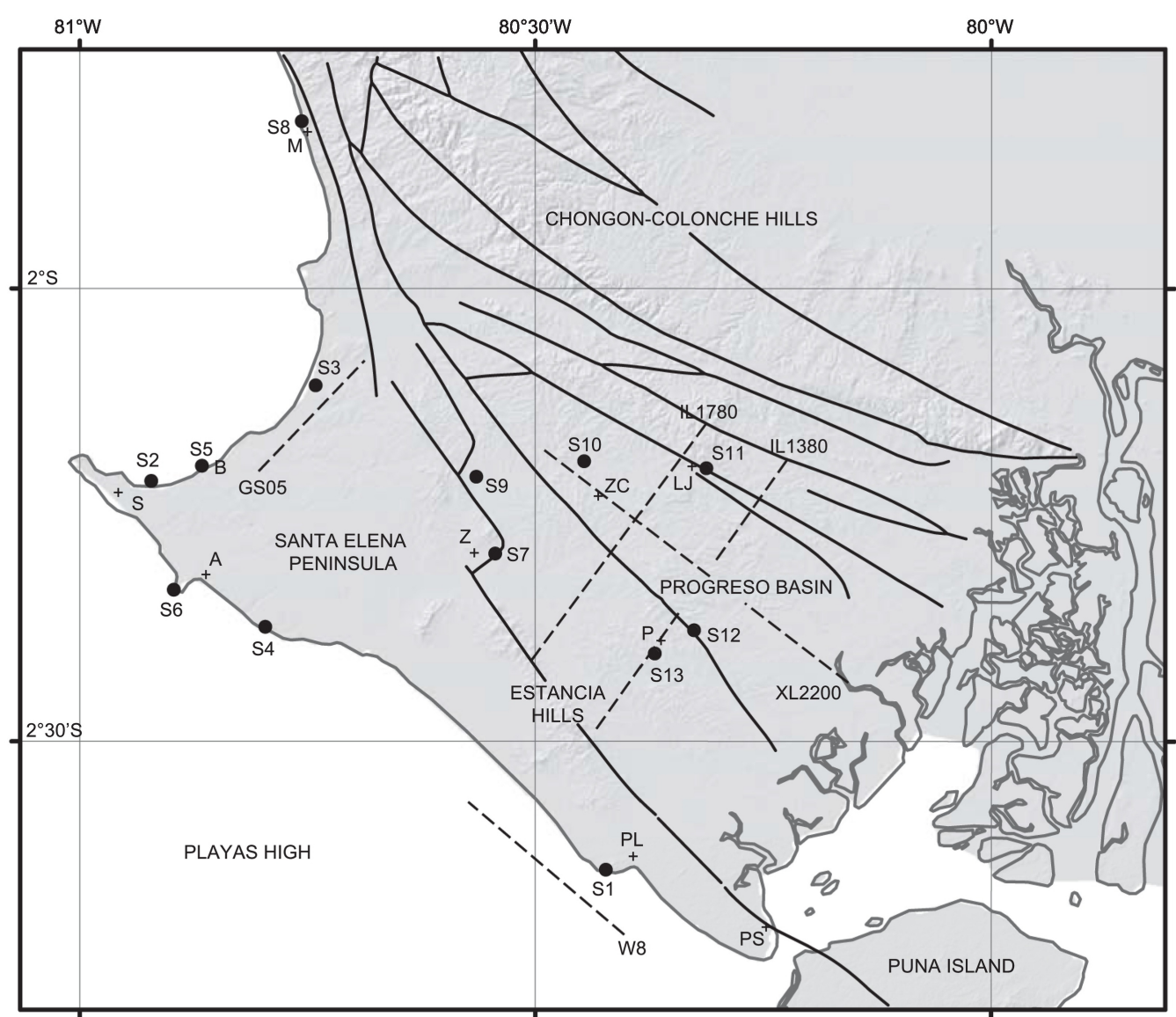

+ Locality

- Studied site

Fault

- - - - - Seismic line

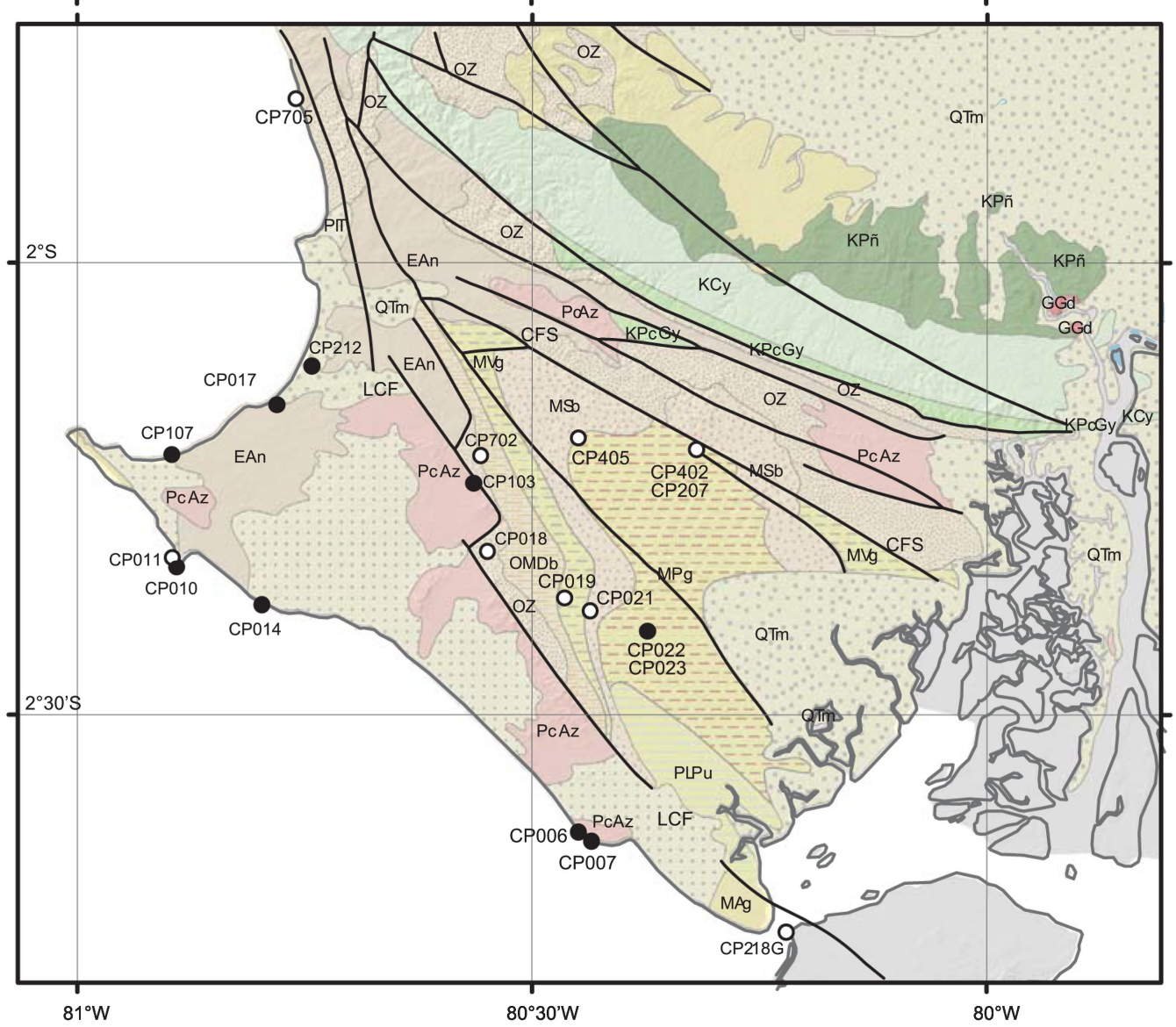

Sample, age first published in Witt et al., 2017

○ Sample, age this work

QTm. Quaternary

PIPu. Puna Fm.

MPg. Progreso Fm.

MSb. Subibaja Fm.

MVg. Villingota Fm.

OMDb. Dos Bocas Fm.

OZ. Zapotal Fm.

EAn. Ancón Gp.

PcAz. Azúcar Fm.

KPcGy. Guayaquil Fm.

KCy. Cayo Fm.

KPñ. Piñón Fm. 


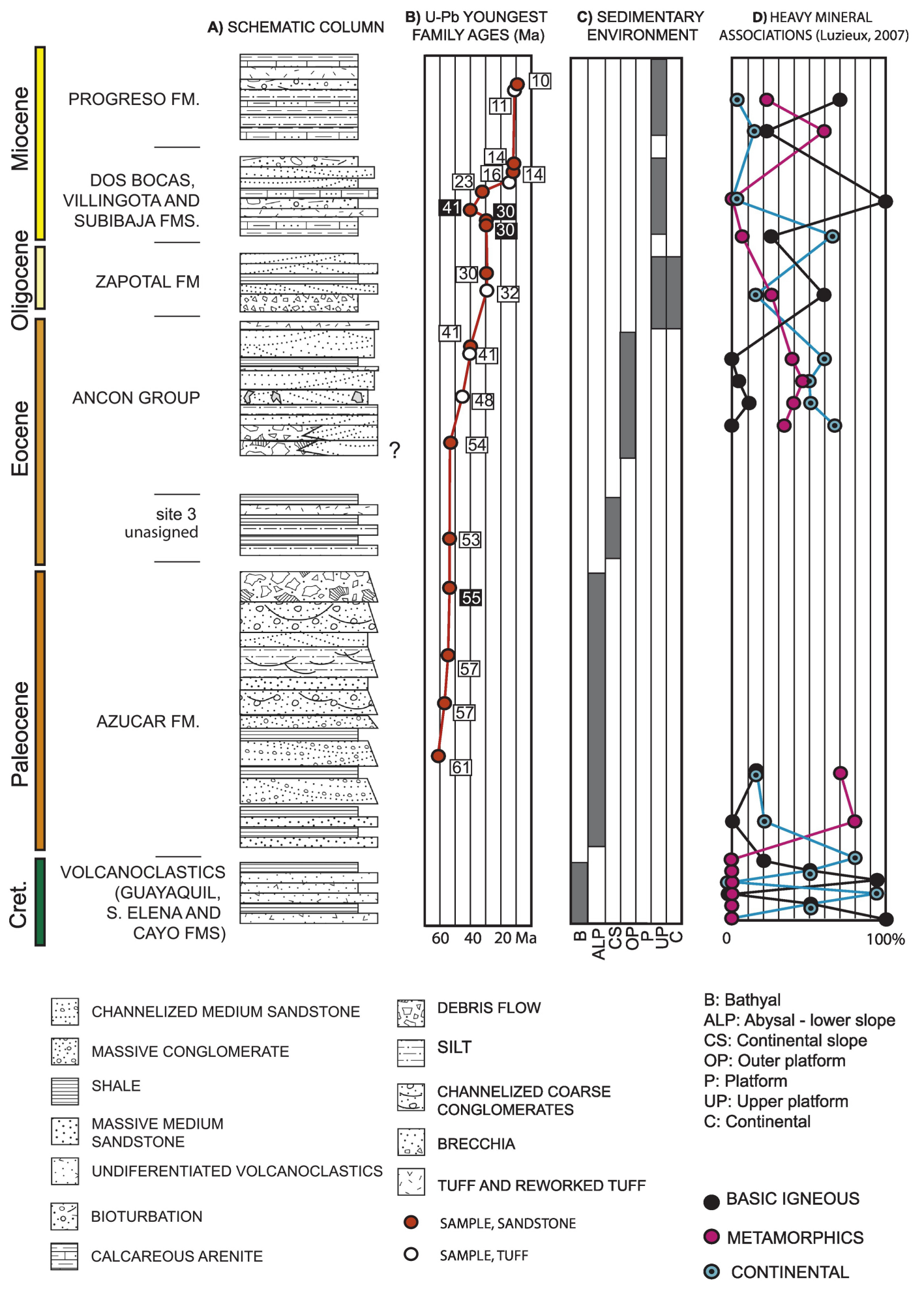



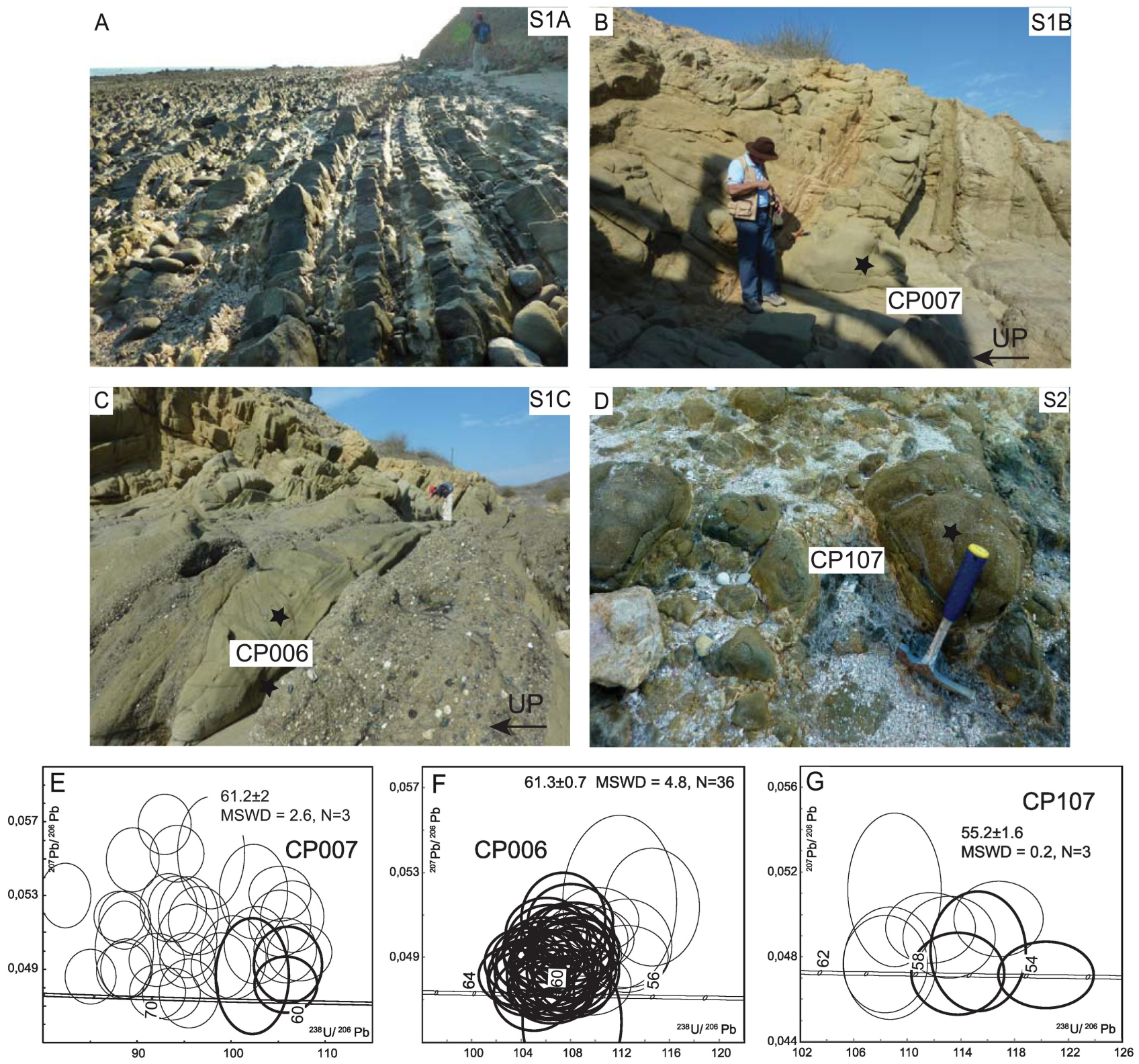

Figure 4 

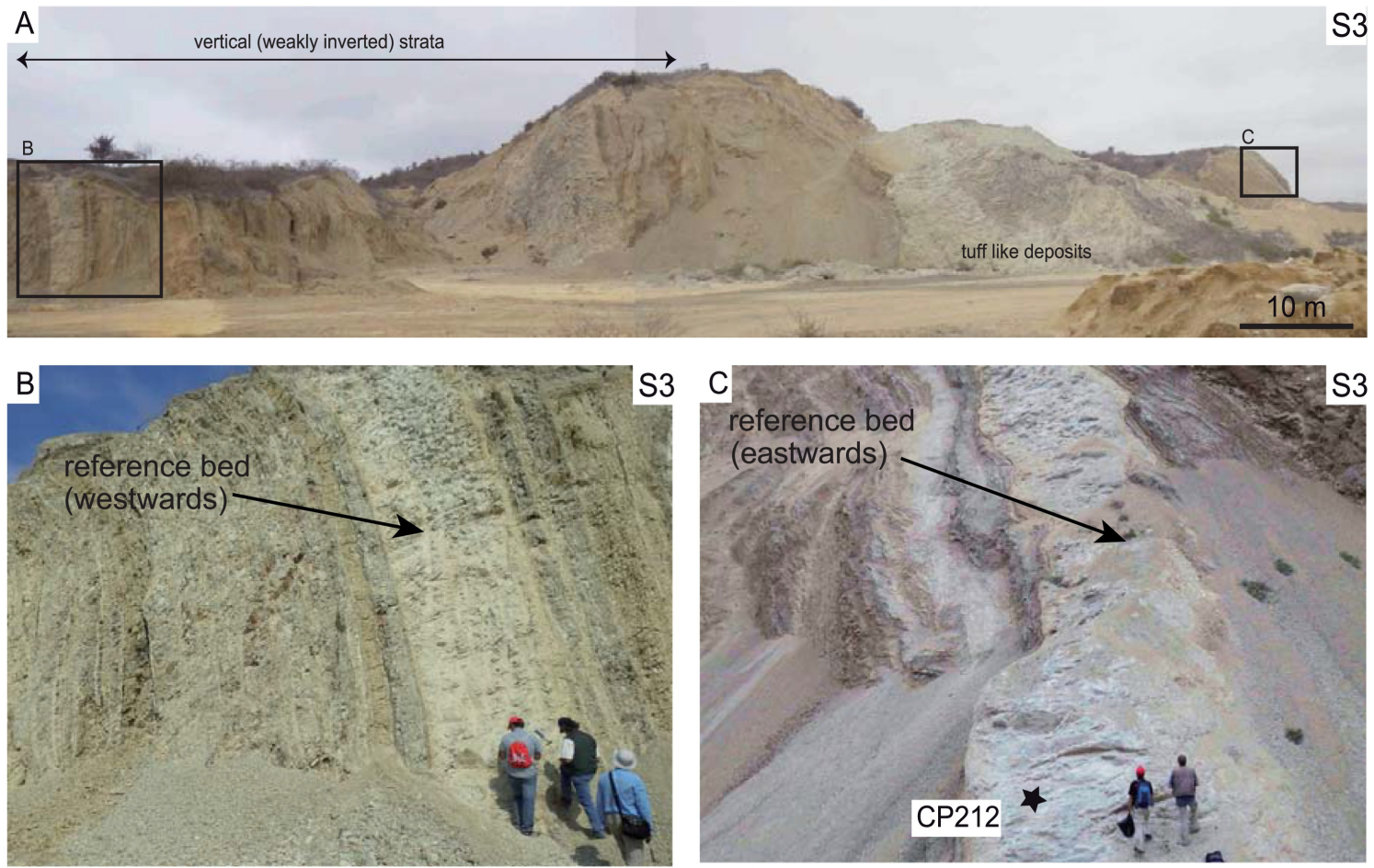

Figure 5 

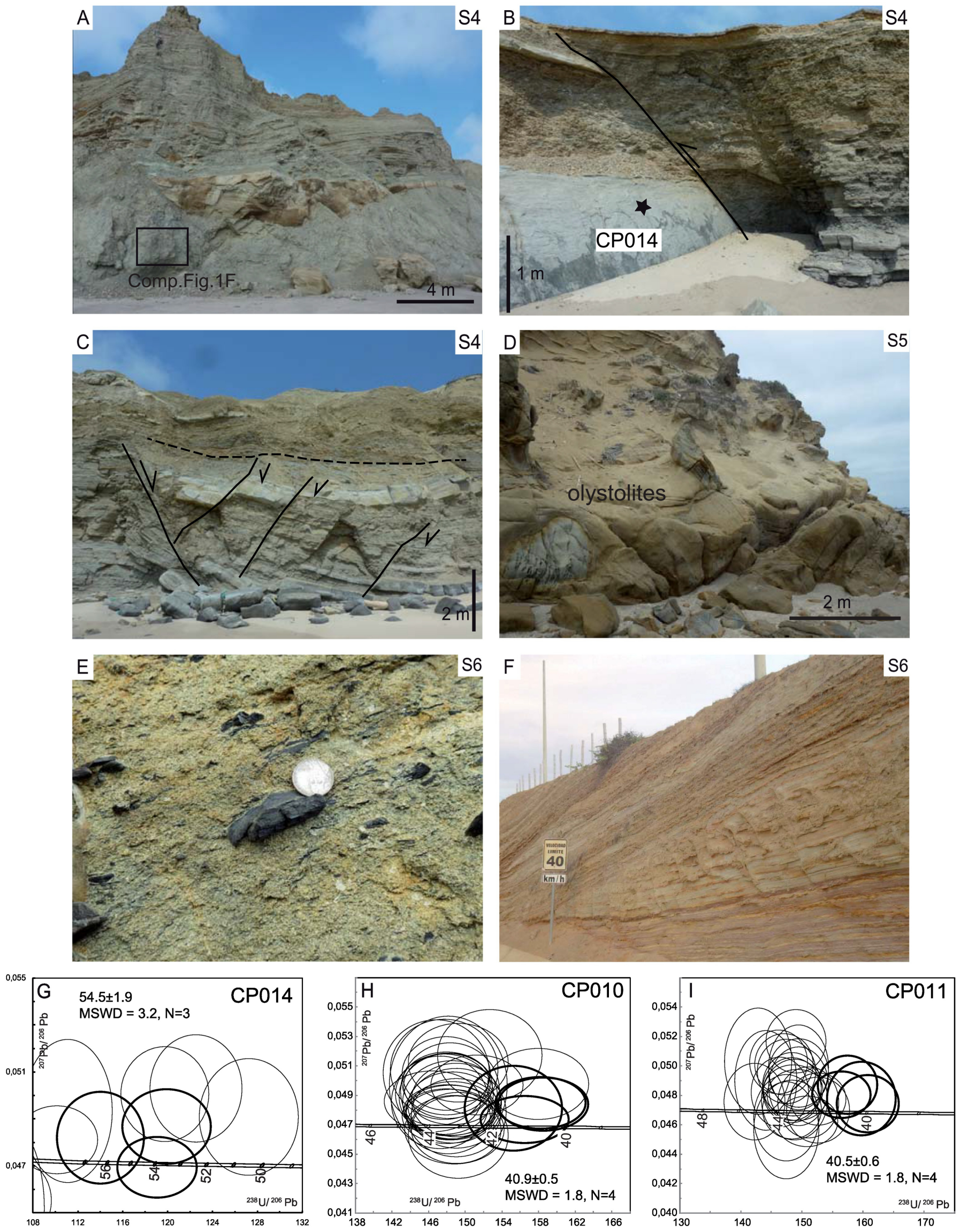

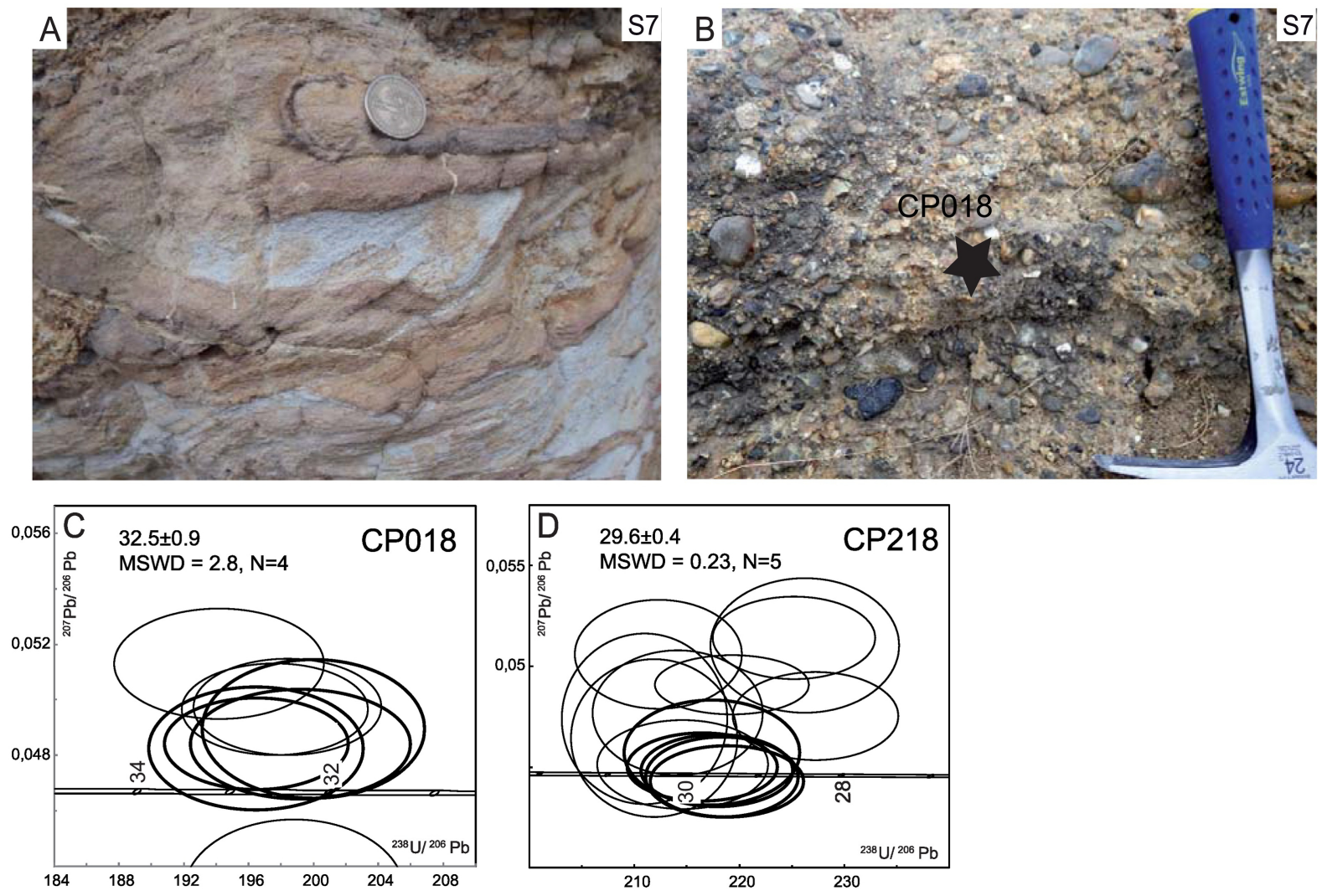

Figure 7 

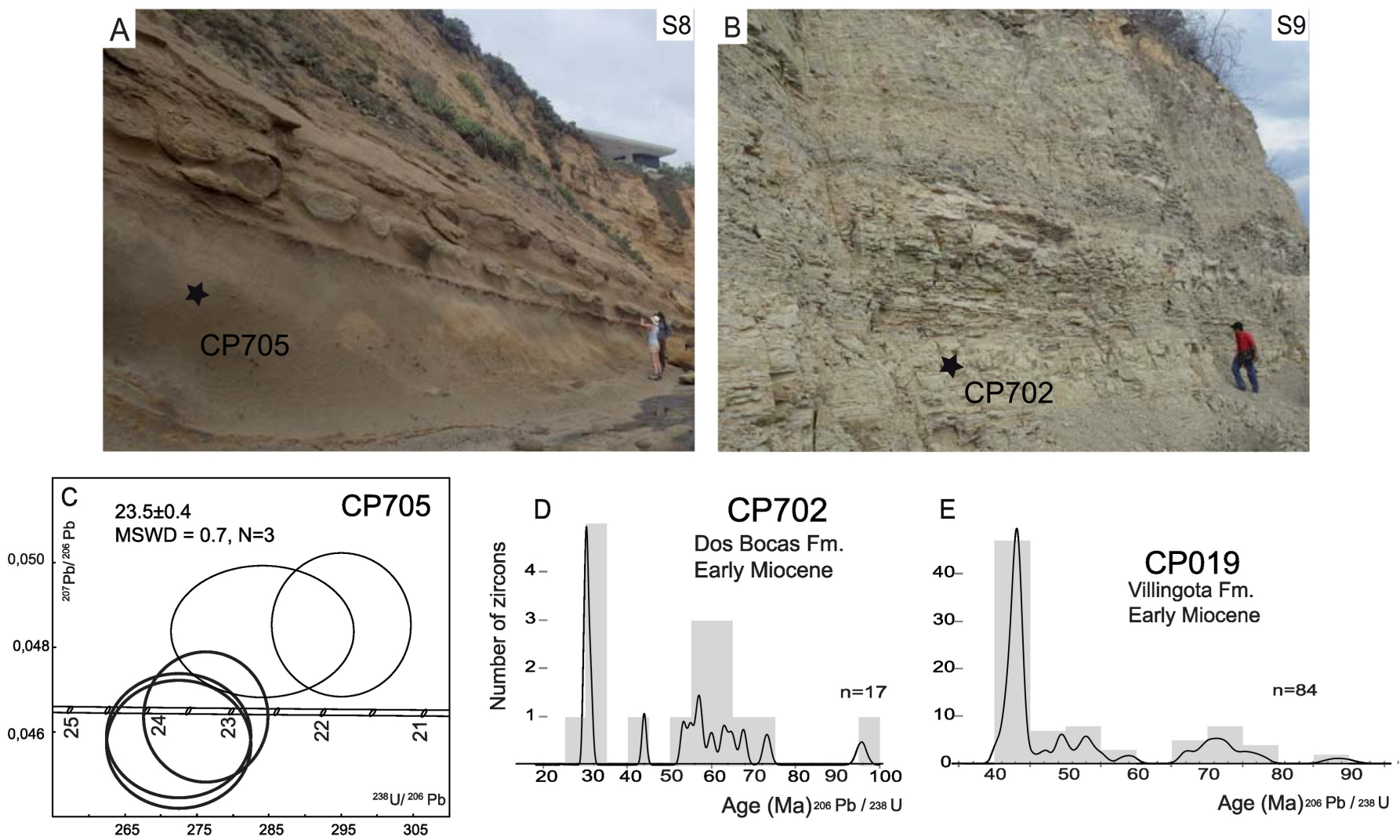

Figure 8 

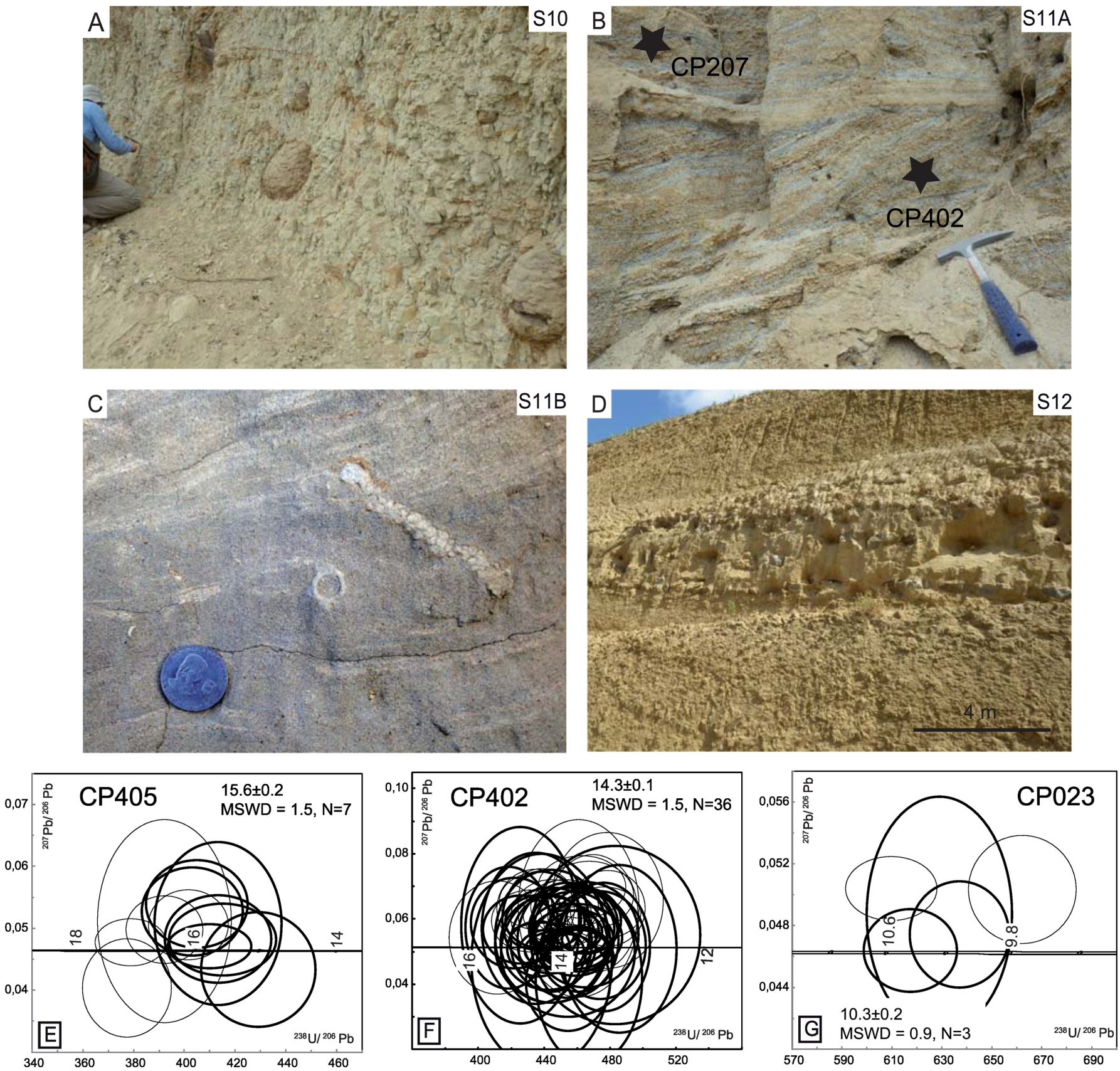

Figure 9 
E.

NW Quaternary

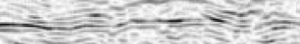

Post accretionary series

1.5

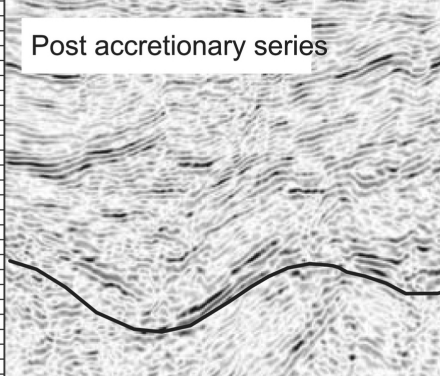

$2-$

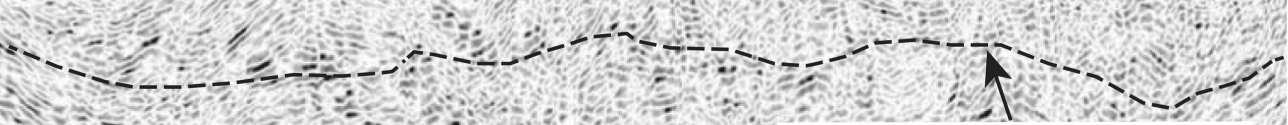

25 -

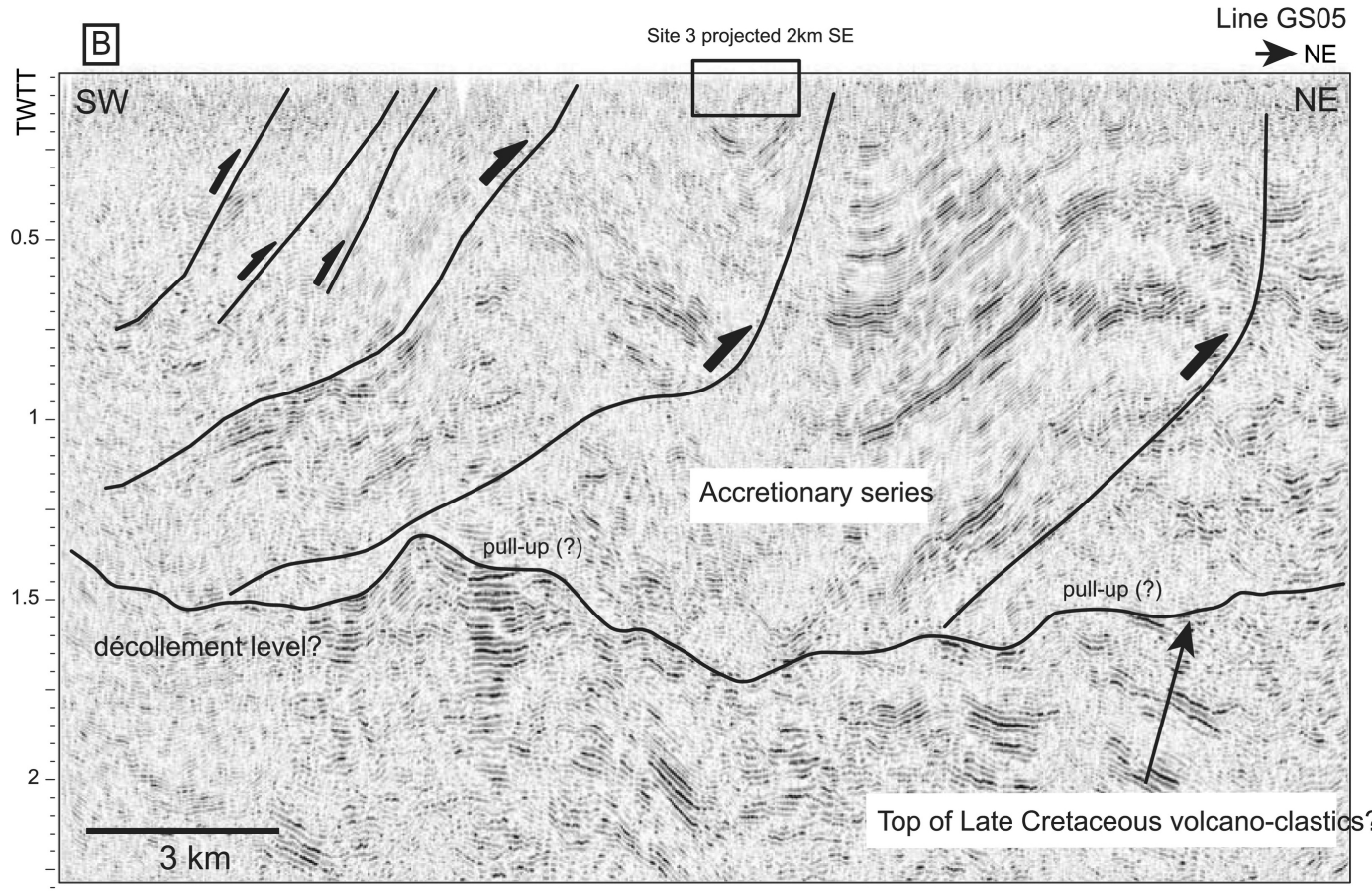


Estancia CP019

Hills (925 m SE) $\mathrm{CP} 021$

ILine 1780



\section{A) Accretion of SW Ecuador}

61-55 Ma

\section{Azúcar Formation}

Piñon Formation and Upper Cretaceous

volcanoclastics

B) Main period of deformation in the accretionary prism 55-54 Ma (?)

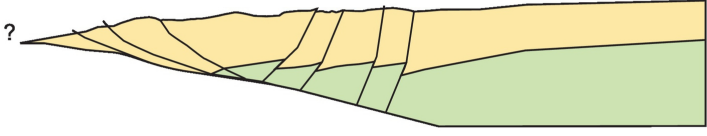

C) Ongoing but weaker accretionary prism deformation Gravity-driven deformation. Upwards shallowing series 54(?)-40 Ma

\section{Ancón Gp.}

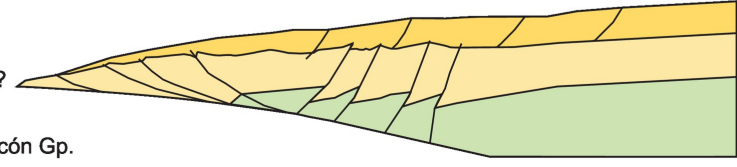

D) Emergence of SW Ecuador (?)

Formation of the Estancia Hills (OFH) and Progreso forearc basin

$32-30 \mathrm{Ma}$

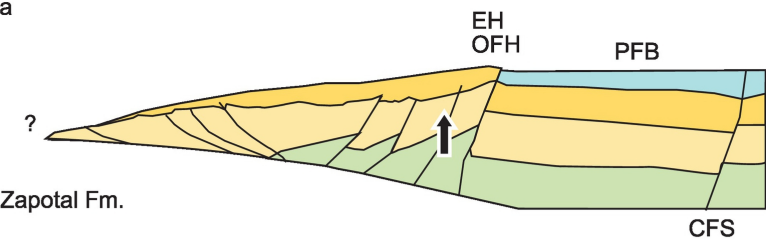

E) Ongoing deformation at the OFH.

Inversion of the Carrizal system. Obstruction of WC sourcing ? 30-16 Ma

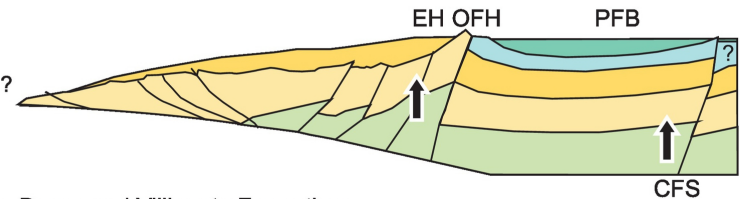

Dos Bocas and Villingota Formations

F) Protected bay, tidal influence 16-10 Ma

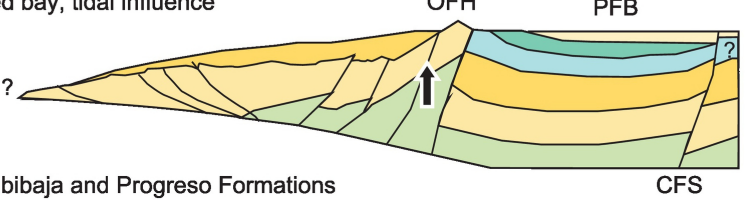

